\title{
Asuhan Keperawatan Jiwa Dengan Masalah Risiko Perilaku Kekerasan Pada Penderita Skizofrenia: Studi Kasus
}

\section{Febri Warni Hulu}

\author{
febriwarnihulu@gmail.com
}

\section{BAB 1 \\ PENDAHULUAN}

\subsection{Latar Belakang}

Kesehatan jiwa merupakan suatu kondisi yang memungkinkan perkembangan fisik, intelektual, dan emosional yang optimal dari seseorang dan perkembangan tersebut berjalan selaras dengan keadaan orang lain (Keliat, 2016). Menurut data WHO (2016), terdapat sekitar 35 juta orang terkena depresi, 60 juta orang terkena bipolar, 21 juta terkena skizofrenia, serta 47,5 juta terkena dimensia. Di Indonesia, dengan berbagai faktor biologis, psikologis dan sosial dengan keanekaragaman penduduk; maka jumlah kasus gangguan jiwa terus bertambah yang berdampak pada penambahan beban negara dan penurunan produktivitas manusia untuk jangka panjang. Data Riskesdas 2018 menunjukkan prevalensi ganggunan mental emosional yang ditunjukkan dengan gejala-gejala depresi dan kecemasan untuk usia 15 tahun ke atas mencapai sekitar 6.1\% dari jumlah penduduk Indonesia. Sedangkan prevalensi gangguan jiwa berat, seperti skizofrenia mencapai sekitar 400.000 orang atau sebanyak 1,7 per 1.000 penduduk. Menurut National Alliance of Mental Illness (NAMI) berdasarkan hasil sensus penduduk Amerika Serikat tahun 2013, di perkirakan 61.5 juta penduduk yang berusia lebih dari 18 tahun mengalami gangguan jiwa, 13,6 juta diantaranya mengalami gangguan jiwa berat seperti skizofrenia

Skizofrenia merupakan suatu gangguan jiwa berat yang bersifat berat dan kronis yang menyerang 20 juta orang di seluruh dunia (WHO, 2019). Skizofrenia merupakan penyakit kronis, parah, dan melumpuhkan, gangguan otak yang di tandai dengan pikiran kacau, waham, delusi, halusinasi, dan perilaku aneh atau katatonik (Pardede, \& Laia. 2020). Skizofrenia merupakan suatu penyakit yang mempengaruhi otak, dan menyebabkan timbulnya pikiran, persepsi, gerakan, perilaku yang aneh dan terganggu (Videbeck, 2015). Tanda dan gejala yang timbul akibat skizofrenia berupa gejala positif dan negatif seperti 
perilaku kekerasan. Resiko perilaku kekerasan merupakan salah satu respon marah yang diespresikan dengan melakukan ancaman, mencederai diri sendiri maupun orang lain. Pada aspek fisik tekanan darah meningkat, denyut nadi dan pernapasan meningkat, marah, mudah tersinggung, mengamuk dan bisa mencederai diri sendiri. Perubahan pada fungsi kognitif, fisiologis, afektif, hingga perilaku dan sosial hingga menyebabkan resiko perilaku kekerasan. Berdasarkan data tahun 2017 dengan resiko perilaku kekerasan sekitar 0,8\% atau dari 10.000 orang menunjukkan resiko perilaku kekerasan sanggatlah tinggi (Pardede,2020). Risiko perilaku kekerasan ini dapat dilihat dari bicara dengan nada keras dan perilaku yang kasar yang disertai kekerasan (Awaludin, 2016).

Perilaku kekerasan merupakan salah satu respon terhadap streesor yang dihadapi oleh seseorang, respon ini dapat menimbulkan kerugian baik kepada diri sendiri, orang lain, maupun lingkungan. Seseorang yang mengalami perilaku kekerasan sering menunjukan perubahan perilaku seperti mengancam, gaduh, tidak bisa diam, mondar-mandir, gelisah, intonasi suara keras, ekspresi tegang, bicara dengan semangat, agresif, nada suara tinggi dan bergembira secara berlebihan. Pada seseorang yang mengalami resiko perilaku kekerasan mengalami perubahan adanya penurunan kemampuan dalam memecahkan masalah, orientasi terhadap waktu, tempat dan orang serta gelisah (Pardede, Siregar, \& Halawa, 2020).

Hasil survey awal yang dilakukan diruang rawat inap Sorik Merapi di RSJ Prof, Dr, M.Ildrem, terdapat 20 orang pasien yang mengalami skizofrenia dengan masalah keperawatan risiko perilaku kekerasan. Sehingga penulis tertarik untuk memberikan asuhan keperawatan pada pasien dengan masalah risiko perilaku kekerasan.

\subsection{Rumusan Masalah}

Bagaimana memberikan asuhan keperawatan jiwa pada Tn.B dengan Risiko Perilaku kekerasan di Rumah Sakit Jiwa Prof.Dr.M. Ildrem di Medan Sumatera Utara

\subsection{Tujuan Penulisan}

Adapun tujuannya sebagai berikut :

\subsubsection{Tujuan Umum}

Mahasiswa mampu memberikan asuhan keperawatan jiwa pada Tn. B dengan Risiko Perilaku Kekerasan di Rumah Sakit Jiwa Prof.Dr.M. Ildrem. 


\subsubsection{Tujuan Khusus}

a. Mahasiswa mampu mengetahui tentang defenisi, tanda \& gejala, factor pencetus, mekanisme koping, penatalaksanaan pada pasien dengan Risiko Perilaku Kekerasan.

b. Mahasiswa mampu melakukan pengkajian pada pasien dengan Risiko Perilaku Kekerasan.

c. Mahasiswa mampu menegakkan diagnosa atau masalah keperawatan pada Tn. B dengan Risiko Perilaku Kekerasan.

d. mampu menetapkan intervensi keperawatan secara menyeluruh pada Tn. B dengan Risiko Perilaku Kekerasan.

e. Mahasiswa mampu melakukan tindakan keperawatan yang nyata pada Tn. B dengan Risiko Perilaku Kekerasan.

f. Mahasiswa mampu mengevaluasi sebagai tolak ukur guna menerapkan asuhan keperawatan pada Tn.B dengan Risiko Perilaku Kekerasan.

g. Mahasiswa mampu mendokumentasikan asuhan keperawatan pada Tn. B dengan Risiko Perilaku Kekerasan. 


\section{BAB 2 \\ TINJAUAN TEORITIS}

\subsection{Konsep Perilaku Kekerasan}

\subsubsection{Defenisi}

Perilaku kekerasan merupakan salah satu respon terhadap streesor yang dihadapi oleh seseorang, respon ini dapat menimbulkan kerugian baik kepada diri sendiri, orang lain, maupun lingkungan. Seseorang yang mengalami perilaku kekerasan sering menunjukan perubahan perilaku seperti mengancam, gaduh, tidak bisa diam, mondar-mandir, gelisah, intonasi suara keras, ekspresi tegang, bicara dengan semangat, agresif, nada suara tinggi dan bergembira secara berlebihan. Pada seseorang yang mengalami resiko perilaku kekerasan mengalami perubahan adanya penurunan kemampuan dalam memecahkan masalah, orientasi terhadap waktu, tempat dan orang serta gelisah (Pardede, Siregar, \& Halawa, 2020).

Perilaku kekerasan adalah salah satu respon terhadap stressor yang dihadapi oleh seseorang yang dihadapi oleh seeorang yang di tunjukan dengan perilaku kekerasan baik pada diri sediri maupun orang lain dan lingkungan baik secara verbal maupun non-verbal. Bentuk perilaku kekerasan yang dilakukan bisa amuk, bermusuhan yang berpotensi melukai, merusak baik fisik maupun kata-kata (Kio, Wardana \& Arimbawa, 2020).

\subsubsection{Tanda dan Gejala Risiko Perilaku Kekerasan}

Menurut Keliat (2016), tanda dan gejala perilaku kekerasan sebagai berikut :

1. Emosi: tidak adekuat, tidak aman, rasa terganggu, marah (dendam), dan jengkel

2. Intelektual: mendominasi, bawel, sarkasme, berdebat, dan meremehkan

3. Fisik: muka merah, pandangan tajam, napas pendek, keringat, sakit fisik, penyalahgunaan zat, tekanan darah meningkat

4. Spiritual: kemahakuasaan, kebijakan/kebenaran diri, keraguan, tidak bermoral, kebejatan, kreativitas terlambat.

5. Sosial : menarik diri, pengasingan, penolakan, kekerasan, ejekan, dan humor 


\subsubsection{Rentang Respons Marah}

Adaptif

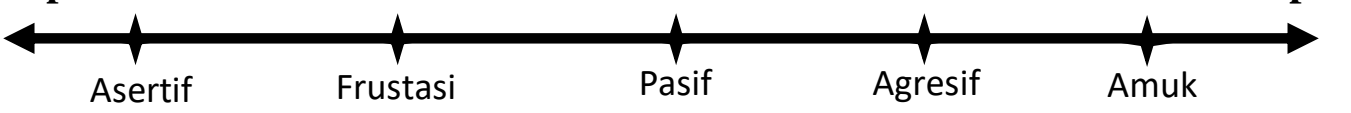

1. Asertif : Kemarahan yang diungkapkan tanpa menyakiti orang lain

2. Frustasi : Kegagalan mencapai tujuan karena tidak realistis atau terhambat

3. Pasif : Respons lanjutan dimana pasien tidak dapat mengungkapkan perasaannya

4. Agresif : Perilaku destruktif tapi masih dapat dikontrol. Orang agresif biasanya tidak mau mengetahui hak orang lain. Dia berpendapat bahwa setiap orang harus bertarung untuk mendapatkan kepentingan sendiri dan mengharapkan perlakuan yang sama dari orang lain.

5. Amuk : Perilaku destruktif dan tidak terkontrol. Yaitu rasa marah dan bermusuhan yang kuat disertai kehilangan control diri. Pada keadaaan ini individu dapat merusak dirinya sendiri maupun orang lain

\section{Gambar 2.2 Hierarki Perilaku Kekerasan} Sumber : (Nurhalimah 2016)

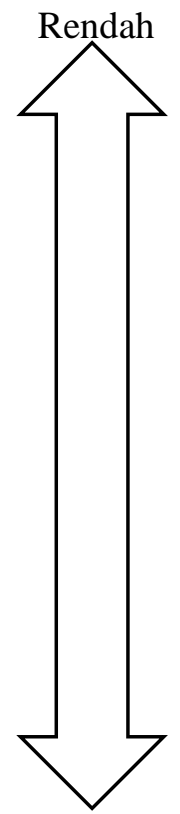

\begin{tabular}{|l|l|}
\hline No. & \multicolumn{1}{|c|}{ Hierarki Perilaku Kekerasan } \\
\hline 1. & Memperlihatkan permusuhan rendah \\
\hline 2. & Keras menuntut \\
\hline 3. & Mendekati orang lain dengan ancaman \\
\hline 4. & Memberi kata-kata ancaman tanpa niat melukai \\
\hline 5. & Menyentuh orang dengan cara yang menakutkan \\
\hline 6. & Memberi kata-kata ancaman dengan cara melukai \\
\hline 7. & $\begin{array}{l}\text { Melukai dalam tingkat ringan tanpa membutuhkan } \\
\text { perawatan medis }\end{array}$ \\
\hline 8. & $\begin{array}{l}\text { Melukai dalam tingkat serius dan memerlukan } \\
\text { perawatan medis }\end{array}$ \\
\hline
\end{tabular}

Tinggi 
Table 1.2 Perbandingan Perilaku Pasif, Asertif, Agresif Sumber (Nurhalimah, 2016)

\begin{tabular}{|c|c|c|c|}
\hline & Pasif & Asertif & Agresif \\
\hline Isi Bicara & $\begin{array}{l}\text { - Negative } \\
\text { - Menghina } \\
\text { - Dapatkah saya } \\
\text { lakukan } \\
\text { - Dapatkah Ia } \\
\text { lakukan } \\
\end{array}$ & $\begin{array}{l}\text { - Positif } \\
\text { - Menghargai diri } \\
\text { sendiri } \\
\text { - Saya dapat/akan } \\
\text { lakukan }\end{array}$ & $\begin{array}{l}\text { - Berlebihan } \\
\text { - Menghina } \\
\text { orang lain } \\
\text { - Anda } \\
\text { selalu/tidak } \\
\text { pernah } \\
\end{array}$ \\
\hline Nada Suara & $\begin{array}{ll}\text { - } & \text { Diam } \\
\text { - Lemah } \\
\text { - } \text { Merengek }\end{array}$ & - Diatur & $\begin{array}{l}\text { - } \text { Tinggi } \\
\text { - } \text { Menuntut }\end{array}$ \\
\hline $\begin{array}{c}\text { Postur/Sikap } \\
\text { Tubuh }\end{array}$ & $\begin{array}{l}\text { - Melotot } \\
\text { - Menundukkan } \\
\text { kepala } \\
\end{array}$ & $\begin{array}{l}\text { - Tegak } \\
\text { - Rileks }\end{array}$ & $\begin{array}{ll}\text { - } & \text { Tenang } \\
\text { - } & \text { Bersandar } \\
\text { kedepan }\end{array}$ \\
\hline $\begin{array}{c}\text { Personal } \\
\text { Space }\end{array}$ & $\begin{array}{l}\text { - Orang lain } \\
\text { dapat masuk } \\
\text { pada } \\
\text { territorial } \\
\text { kehidupannya }\end{array}$ & $\begin{array}{l}\text { - Menjaga jarak } \\
\text { yang } \\
\text { menyenangkan } \\
\text { - Mempertahankna } \\
\text { hak } \\
\text { tempat/teritorialnya }\end{array}$ & $\begin{array}{l}\text { - Memasuki } \\
\text { territorial } \\
\text { orang }\end{array}$ \\
\hline Gerakan & $\begin{array}{l}\text { - Minimal } \\
\text { - Lemah } \\
\text { - Resah } \\
\end{array}$ & $\begin{array}{l}\text { - } \begin{array}{l}\text { Memperlihatkan } \\
\text { Gerakan yang } \\
\text { sesuai }\end{array} \\
\end{array}$ & $\begin{array}{ll}\text { - } & \text { Mengancam } \\
\text { - Ekspansi } \\
\text { Gerakan } \\
\end{array}$ \\
\hline $\begin{array}{c}\text { Kontak } \\
\text { Mata }\end{array}$ & $\begin{array}{l}\text { - Sedikit atau } \\
\text { tidaak }\end{array}$ & $\begin{array}{l}\text { - Sekali-sekali sesuai } \\
\text { dengan kebutuhan } \\
\text { interaksi }\end{array}$ & - Melotot \\
\hline
\end{tabular}

\subsubsection{Faktor Penyebab Risiko Perilaku Kekerasan}

Perilaku kekerasan atau amuk dapat disebabkan oleh frustasi, takut, intimidasi atau manipulasi. Perilaku kekerasan merupakan hasil konflik emosional yang belum dapat diselesaikan. Peerilaku kekerasan juga menggambarkan rasa tidak aman, kebutuhan akan perhatian dan ketergantungan pada orang lain. Pada pasien gangguan jiwa perilaku kekerasan bisa disebabkan adanya perubahan sensorik persepsi berupa halusinasi, baik dengar, visual maupun lainnya. Pasien merasa diperintah oleh suara suara atau bayangan yang dilihatnya untuk melakukan kekerasan atau pasien merasa marah terhadap suara-suara atau bayangan yang mengejeknya. (Kusnadi, 2018).

Selain melihat respon perilaku melalui tingkah laku pasien, pada pengkajian perlu juga untuk melihat penyebab terjadinya perilaku kekerasan yang dilakukan pasien. 
Menurut Nurhalimah (2016) penyebab terjadinya perilaku kekerasan dapat dijelaskan dengan menggunakan konsep stres adaptasi Struart yang meliputi factor predisposisi (faktor yang melatarbelakangi) dan faktor presipitasi (faktor yang memicu adanya masalah).

\section{a. Faktor Predisposisi}

Hal-hal yang dapat mempengaruhi terjadinya perilaku kekerasan meliputi :

1.) Faktor Biologis

Hal yang dikaji pada faktor biologis meliputi adanya faktor herediter yaitu adanya anggota keluarga yang sering memperlihatkan atau melakukan perilaku kekerasan, adanya anggota keluarga yang mengalami gangguan jiwa, adanya riwayat penyakit atau trauma kepala, dan riwayat penggunaan NAPZA (narkotika, psikotropika, dan zat adiktif lainnya). Sedangkan menurut Sutejo (2017) dari faktor-faktor tersebut masih ada teori-teori yang menjelaskan tiap faktor.

a.) Teori dorongan naluri (Instinctual drive theory)

Teori ini menyatakan bahwa perilaku kekerasan disebabkan oleh suatu dorongan kebutuhan dasar yang kuat. Penelitian neurobiologi mendapatkan bahwa adanyapemberian stimulus elektris ringan pada hipotalamus (yang berada di tengah sistem limbik) binatang ternyata menimbulkan perilaku agresif.

b.) Teori psikomatik (Psycomatic theory)

Pengalaman marah dapat diakibatkan oleh respon psikologi terhadap stimulus eskternal maupun internal. Sehingga sistem limbik memiliki peran sebagai pusat untuk mengekspresikan maupun menghambat rasa marah.

2.) Faktor Psikologi

a.) Frustation aggresion theory

Menerjemahkan bahwa bila usaha seseorang untuk mencapai suatu tujuan mengalami hambatan maka akan timbul dorongan agresif yang pada gilirannya akan memotivasi perilaku yang dirancang untuk melukai orang atau objek. Hal ini dapat terjadi apabila keinginan individu untuk mencapai sesuatu gagal atau terhambat. keadaan frustasi dapat mendorong individu untuk berperilaku agresif karena perasaan frustasi akan berkurang melalui perilaku kekerasan. 
b.) Teori Perilaku (Behaviororal theory)

Kemarahan merupakan bagian dari proses belajar. Hal ini dapat dicapai apabila tersedia fasilitas atau situasi yang mendukung. Reinforcement yang diterima saat melakukan kesalahan sering menimbulkan kekerasan di dalam maupun di luar rumah.

c.) Teori Eksistensi (Existential theory)

Salah satu kebutuhan dasar manusia adalah bertindak sesuai perilaku. Apabila kebutuhan tersebut tidak dipenuhi melalui perilaku konstruktif, maka individu akan memenuhi kebutuhannya melalui perilaku destruktif.

\section{3.) Faktor Sosial Budaya}

Teori lingkungan sosial (social environment theory) menyatakan bahwa lingkungan sosial sangat mempengaruhi sikap individu dalam mengekspresikan marah. Norma budaya dapat mendukung individu untuk berespon asertif atau agresif. Perilaku kekerasan dapat dipelajari secara langsung melalui proses sosialisasi (Social learning theory). Social learning theory menerjemahkan bahwa agresi tidak berbeda dengan respon-respon yang lain. Agresi dapat dipelajari melalui observasi atau imitasi, dan semakin sering mendapatkan penguatan maka semakin besar kemungkinan untuk terjadi. Sehingga seseorang akan berespon terhadap keterbangkitan emosionalnya secara agresif sesuai dengan respon yang dipelajarinya. Pembelajaran tersebut bisa internal maupun eksternal. Contoh internal : orang yang mengalami keterbangkitan seksual karena menonton film erotis menjadi lebih agresif dibandingkan mereka yang tidak menonton film tersebut; seorang anak yang marah karena tidak boleh beli es krim kemudian ibunya memberinya es agar si anak berhenti marah, anak tersebut akan belajar bahwa bila ia marah maka ia akan mendapatkan apa yang ia inginkan. Contoh eksternal : seorang anak menunjukan perilaku agresif setelah melihat seorang dewasa mengekspresikan berbagai bentuk perilaku agresif terhadap sebuah boneka. Kultural dapat pula mempengaruhi perilaku kekerasan. Adanya norma dapat membantu mendefinisikan ekspresi agresif mana yang dapat diterima atau tidak dapat diterima. Sehingga dapat membantu individu untuk mengekspresikan marah dengan cara yang aserif. 


\section{b. Faktor Presipitasi}

Faktor presipitasi perilaku kekerasan pada seiap individu bersifat unik, berbeda satu orang dengan yang lain. Faktor ini berhubungan dengan pengaruh stresor yang mencetuskan perilaku kekerasan bagi setiap individu. Stresor tersebut dapat merupakan penyebab yang berasal dari dalam maupun dari luar individu. Stresor dari dalam berupa kehilangan relasi atau hubungan dengan orang yang dicintai atau berarti seperti kehilangan keluarga, sahabat yag dicintai, kehilangan rasa cinta, kekhawatiran terhadap penyakit, fisik dan lain-lain. Sedangkan stresor dari luar berupa serangan fisik,

\section{2.) Faktor Psikologi}

\section{a.) Frustation aggresion theory}

Menerjemahkan bahwa bila usaha seseorang untuk mencapai suatu tujuan mengalami hambatan maka akan timbul dorongan agresif yang pada gilirannya akan memotivasi perilaku yang dirancang untuk melukai orang atau objek. Hal ini dapat terjadi apabila keinginan individu untuk mencapai sesuatu gagal atau terhambat. keadaan frustasi dapat mendorong individu untuk berperilaku agresifkarena perasaan frustasi akan berkurang melalui perilaku kekerasan.

b.) Teori Perilaku (Behaviororal theory)

Kemarahan merupakan bagian dari proses belajar. Hal ini dapat dicapai apabila tersedia fasilitas atau situasi yang mendukung. Reinforcement yang diterima saat melakukan kesalahan sering menimbulkan kekerasan didalam maupun di luar rumah.

c.) Teori Eksistensi (Existential theory)

Salah satu kebutuhan dasar manusia adalah bertindak sesuai perilaku. Apabila kebutuhan tersebut tidak dipenuhi melalui perilaku konstruktif, maka individu akan memenuhikebutuhannya melalui perilaku destruktif.

3.) Faktor Sosial Budaya

Teori lingkungan sosial (social environment theory) menyatakan bahwa lingkungan sosial sangat mempengaruhi sikap individu dalam mengekspresikan marah. Norma budaya dapat mendukung individu untuk berespon asertif atau agresif. Perilaku kekerasan dapat dipelajari secara langsung melaluiproses sosialisasi (Social learning theory). Social learning 
theory menerjemahkan bahwa agresi tidak berbeda dengan respon-respon yang lain. Agresi dapat dipelajari melalui observasi atau imitasi, dan semakin sering mendapatkanpenguatan maka semakin besar kemungkinan untuk terjadi. Sehingga seseorang akan berespon terhadap keterbangkitan emosionalnya secara agresif sesuai dengan respon yang dipelajarinya. Pembelajaran tersebut bisa internal maupun eksternal. Contoh internal : orang yang mengalami keterbangkitan seksual karena menonton film erotis menjadi lebih agresif dibandingkan mereka yang tidak menonton film tersebut; seorang anak yang marah karena tidak boleh beli es krim kemudian ibunya memberinya es agar si anak berhenti marah, anak tersebut akan belajar bahwa bila ia marah maka ia akan mendapatkan apa yang ia inginkan. Contoh eksternal : seorang anak menunjukan perilaku agresif setelah melihat seorang dewasa mengekspresikan berbagai bentuk perilaku agresif terhadap sebuah boneka. Kultural dapat pula mempengaruhi perilaku kekerasan. Adanya norma dapat membantu mendefinisikan ekspresi agresif mana yang dapat diterima atau tidak dapat diterima. Sehingga dapat membantu individu untuk mengekspresikan marah dengan cara yang asertif.

a. Faktor Presipitasi

Faktor presipitasi perilaku kekerasan pada seiap individu bersifat unik, berbeda satu orang dengan yang lain. Faktor ini berhubungan dengan pengaruh stresor yang mencetuskan perilaku kekerasan bagi setiap individu. Stresor tersebut dapat merupakan penyebab yang berasal dari dalam maupun dari luar individu. Stresordari dalam berupa kehilangan relasi atau hubungan dengan orang yang dicintai atau berarti seperti kehilangan keluarga, sahabat yag dicintai, kehilangan rasa cinta, kekhawatiran terhadap penyakit, fisikdan lain-lain. Sedangkan stresor dari luar berupa serangan fisik,kehilangan, kematian, lingkungan yang terlalu ribut, kritikan yang mengarah pada penghinaan, tindakan kekerasan.kehilangan, kematian, lingkungan yang terlalu ribut, kritikan yang mengarah pada penghinaan, tindakan kekerasan.

b. Faktor Risiko

Menurut Nanda (dalam Sutejo 2017) menyatakan faktor- faktor risiko dan risiko perilaku kekerasan terhadap diri sendiri (risk for self-directed 
violence) dan risiko perilaku kekerasan terhadap orang lain (risk for otherdirected violence).

1.) Risiko perilaku kekerasan terhadap diri sendiri (risk for self- directed violence)

a. Usia $\geq 45$ tahun

b. 15-19 tahun

c. Isyarat tingkah laku ((menulis catatan cinta yang sedih, menyatakan pesan bernada kemarahan kepada orang tertentu yang telah menolak individu tersebut, dll)

d. Konflik mengenai orientasi seksual

e. Konflik dalam hubungan interpersonal

f. Pengangguran atau kehilangan pekerjaan (masalah pekerjaan)

g. Terlibat dalam tindakan seksual autoerotik

h. Sumber daya personal yang tidak memadai

i. Status perkawinan (sendiri, menjanda, bercerai)

j. Isu kesehatan mental (depresi, psikosis, gangguan kepribadian, penyalahgunaan zat.

k. Pekerjaan (profesional, eksekutif, administrator, atau pemilik bisnis, dll)

1. Pola kesulitan dalam keluarga (riwayat bunuh diri, sesuatu yang bersifat kekerasan atau konfliktual)

m. Isu kesehatan fisik

n. Gangguan psikologis

o. Isolasi sosial

p. Ide bunuh diri

q. Rencana bunuh diri

r. Riwayat upacara bunuh diri berulang

s. Isyarat verbal (membicarakan kematian, menanyakan tentang dosis mematikan suatu obat, dll)

2.) Risiko perilaku kekerasan terhadap orang lain (risk for other-violence)

a. Akses atau ketersediaan senjata

b. Alterasi (gangguan) fungsi kognitif

c. Perilaku kejam terhadap binatang 
d. Riwayat kekerasan masa kecil, baik secara fisik, psikologis, maupun seksual

e. Riwayat penyalahgunaan zat

f. Riwayat menyaksikan kekerasan dalam keluarga

g. Impulsif

h. Pelanggaran atau kejahatan kendaraan bermotor (seperti pelanggaran lalu lintas, pengguanaan kendaraan bermototr untuk melampiaskan amarah)

i. Bahasa tubuh negatif ( seperti kekauan, mengepalkan tinju/ukulan, hiperaktivitas, dll)

j. Gangguan neurologis (trauma kepala, gangguan serangan, kejang, dll)

$\mathrm{k}$. Intoksikasi patologis

1. Riwayat melakukan kekerasan tidak langsung (kencing dilantai, menyobek objek di dinding, melempar barang, memecahkan kaca, membanting pintu, dll)

m. Pola perilaku kekerasan terhadap orang lain (menendang, memukul, menggigit, mencakar, upaya perkosaan, memperkosa, pelecehan seksual, mengencingi orang, dll)

n. Pola ancaman kekerasan (ancaman secara verbal terhadap objek atau orang lain, menyumpah serapah, gestur atau catatan mengancam, ancaman seksual, dll)

o. Pola perilaku kekerasan antisosial (mencuri, meimnjam dengan memaksa, penolakan terhadap medikasi, dll)

\subsubsection{Mekanisme Koping}

Menurut Prastya, \& Arum (2017). Perawat perlu mengidentifikasi mekanisme koping klien, sehingga dapat membantu klien untuk mengembangkan koping yang konstruktif dalam mengekpresikan kemarahannya.Mekanisme koping yang umum digunakan adalah mekanisme pertahanan ego seperti displacement, sublimasi, proyeksi, represif, denial dan reaksi formasi.

Perilaku yang berkaitan dengan risiko perilaku kekerasan antara lain:

a. Menyerang atau menghindar 
Pada keadaan ini respon fisiologis timbul karena kegiatan system syaraf otonom bereaksi terhadap sekresi epinefrin yang menyebabkan tekanan darah meningkat, takikardi, wajah marah, pupil melebar, mual, sekresi HCL meningkat, peristaltik gaster menurun, kewaspadaan juga meningkat, tangan mengepal, tubuh menjadi kaku dan disertai reflek yang cepat.

b. Menyatakan secara asertif

Perilaku yang sering ditampilkan individu dalam mengekspresikan kemarahannya yaitu dengan perilaku pasif, agresif dan perilaku asertif adalah cara yang terbaik, individu dapat mengekspresikan rasa marahnya tanpa menyakiti orang lain secara fisik maupun psikologis dan dengan perilaku tersebut individu juga dapat mengembangkan diri.

c. Memberontak

Perilaku muncul biasanya disertai kekerasan akibat konflik perilaku untuk menarik perhatian orang lain.

d. Perilaku kekerasan

Tindakan kekerasan atau amuk yang ditujukan akibat konflik perilaku untuk menarik perhatian orang lain.

\subsubsection{Penatalaksanaan}

Yang diberikan pada klien yang mengalami gangguan jiwa amuk ada 2 yaitu:

1. Medis

a. Nozinan, yaitu sebagai pengontrol perilaku psikososial.

b. Halloperidol, yaitu mengontrol psikosis dan prilaku merusak diri.

c. Thrihexiphenidil, yaitu mengontro perilaku merusak diri dan menenangkan hiperaktivitas.

d. ECT (Elektro Convulsive Therapy), yaitu menenangkan klien bila mengarah pada keadaan amuk.

2. Penatalaksanaan keperawatan
a. Psikoterapeutik
b. Lingkungan terapieutik
c. Kegiatan hidup sehari-hari (ADL)
d. Pendidikan kesehatan 


\subsection{Konsep Asuhan Keperawataan Jiwa}

\subsubsection{Pengkajian}

1. Identitas

Nama, umur, jenis kelamin, No MR, tanggal masuk RS, tangal pengkajian.

2. Alasan masuk

Biasanya klien masuk dengan alasan sering mengamuk tanpa sebab, memukul, membanting, mengancam, menyerang orang lain, melukai diri sendiri, mengganggu lingkungan, bersifat kasar dan pernah mengalami gangguan jiwa dimasa lalu kambuh karena tidak mau minum obat secara teratur (Keliat,2016).

3. Faktor Predisposisi

a. Biasanya klien pernah mengalami gangguan jiwa pada masa lalu dan pernah dirawat atau baru pertama kali mengalami gangguan jiwa (Parwati, Dewi \& Saputra 2018).

b. Biasanya klien berobat untuk pertama kalinya kedukun sebagai alternative serta memasung dan bila tidak berhasil baru di bawa kerumah sakit jiwa.

c. Trauma. Biasnya klien pernah mengalami atau menyaksikan penganiayaan fisik, seksual, penolakan, dari lingkungan.

d. Biasanya ada anggota keluarga yang mengalami gangguan jiwa, kalau ada hubungan dengan keluarga, gejala, pengobatan dan perawatan.

e. Biasanya klien pernah mengalami pengalaman masa lalu yang tidak menyenangkan misalnya, perasaan ditolak, dihina, dianiaya, penolakan dari lingkungan

4. Fisik Pengkajian fisik

a. Ukur dan observasi tanda-tanda vital seperti tekanan darah akan bertambah naik, nadi cepat, suhu, pernapasan terlihat cepat.

b. Ukur tinggi badan dan berat badan.

c. Yang kita temukan pada klien dengan prilaku kekerasan pada saat pemeriksaan fisik (mata melotot, pandangan tajam, tangan mengepal, rahang mengatup, wajah memerah)

d. Verbal (mengancam, mengupat kata-kata kotor, berbicara kasar dan ketus).

5. Psikososial

a. Genogram 
Genogram dibuat 3 generasi keatas yang dapat menggambarkan hubungan klien dengan keluarga. Tiga generasi ini dimaksud jangkauan yang mudah diingat oleh klien maupu keluarg apa dasaat pengkajian.

b. Konsep diri

Biasanya ada anggota tubuh klien yang tidak disukai klien yang mempengaruhi keadaan klien saat berhubungan dengan orang lain sehingga klien merasa terhina, diejek dengan kondisinya tersebut.

c. Identitas

Biasanya pada klien dengan prilaku kekerasan tidak puas dengan pekerjaannya, tidak puas dengan statusnya, baik disekolah, tempat kerja dan dalam lingkungan tempat tinggal

d. Harga diri

Biasanya klien dengan risiko prilaku kekerasan hubungan dengan orang lain akan terlihat baik, harmoni sata terdapat penolakan atau klien merasa tidak berharga, dihina, diejek dalam lingkungan keluarga maupun diluar lingkungan keluarga.

1. Peran diri

Biasanya klien memiliki masalah dengan peranatau tugas yang diembannya dalam keluarga, kelompok atau masyarakat dan biasanya klien tidak mampu melaksanakan tugas dan peran tersebut dan merasa tidak berguna.

2. Ideal diri

Biasanya klien memilki harapan yang tinggi terhadap tubuh, posisi dan perannya baik dalam keluarga, sekolah, tempat kerja dan masyarakat.

6. Hubungan sosial

a. Orang yang berarti Tempat mengadu, berbicara

b. Kegiatan yang diikuti klien dalam masyarakat dan apakah klien berperan aktif dalam kelompok tersebut

c. Hambatan dalam berhubungan dengan orang lain/tingkat keterlibatan klien dalam hubungan masyarakat.

7. Spiritual

a. Nilai dan keyakinan

b. Biasanya klien mengatakan bahwa dia tidak mengalami gangguan jiwa.

c. Kegiatan ibadah 
d. Biasaya dalam selama sakit klien jarang melakukan ibadah.

8. Status mental

Penampilan.

Biasanya penampilan klien kotor.

Pembicaraan.

Biasanya pada klien prilaku kekerasan pada saat dilakukan pengkajian bicara cepat,keras, kasar, nada tinggi dan mudah tersinggung.

Aktivitas motorik

Biasanya aktivitas motoric klien dengan prilaku kekerasan akan terlihat tegang, gelisah, gerakan otot muka berubah- ubah, gemetar, tangan mengepal, dan rahang dengan kuat.

Alam perasaan

Biasanya akan merasa sedih dan menyesali apa yang telah dilakukan

Efek

Biasanya klien mudah tersinggung dan sering marah-marah tanpa sebab

Interaksi selama wawancara

Biasanya klien dengan risiko prilaku kekerasan akan terlihat bermusuhan, curiga, tidak kooperatif, tidak mau menatap lawan bicara dan mudah tersinggung.

Persepsi

Biasanya klien dengan prilaku kekerasan masih dapat menjawab pertanyaan dengan jelas.

Isi Pikir

Biasanya klien meyakini dirinya tidak sakit, dan baik-baik saja.

Tingkat kesadaran

Biasanya klien prilaku kekerasan kadang tampak bingung,

Memori

Biasanya klien diwaktu wawancara dapat mengingat kejadian yang terjadi dan mengalami gangguan daya ingat jangka panjang.

Kemampuan penilaian

Biasanya klien mengalami kemampuan penilaian ringan dan sedang dan tidak mampu mengambil keputusan

Daya fikir diri

Biasanya klien mengingkari penyakit yang dideritanya 
9. Kebutuhan persiapan pulang

a.) Makan

Biasanya klien tidak mengalami perubahan

\section{b.) $\mathrm{BAB} / \mathrm{BAK}$}

Biasanya klien dengan risiko prilaku kekerasan tidak ada gangguan

c.) Mandi

Biasanya klien jarang mandi, tidak menyikat gigi, jarang mencuci rambut dan bercukur atau berhias. Badan klien sangat bau dan kotor, dan klien hanya melakukan kebersihan diri jika disuruh.

d.) Berpakaian

Biasanya klien jarang mengganti pakaian, dan tidak mau berdandan. Klien tidak mampu mengenakan pakaian dengan sesuai dan klien tidak mengenakan alas kaki

e.) Istirahat dan tidur

Biasanya klien tidak melakukan persiapan sebelum tidur, seperti: menyikat gigi, cucu kaki, berdoa. Dan sesudah tidur. Seperti: merapikan tempat tidur, mandi atau cuci muka dan menyikat gigi. Frekuensi tidur klien berubah-ubah, kadang nyenyak dan kadang gaduh atau tidak tidur.

f.) Penggunaan obat

Biasanya klien mengatakan minum obat 3 kali sehari dan klien tidak mengetahui fungsi obat dan akibat jika putus minum obat.

g.)Pemeliharaan Kesehatan

Biasanya klien tidak memperhatikan kesehatannya, dan tidak peduli tentang bagaimana cara yang baik untuk merawat dirinya.

h.) Aktifitas didalam rumah

Biasanya klien mampu merencanakan, mengolah, dan menyajikan makanan, merapikan rumah, mencuci pakaian sendiri dan mengatur biaya sehari-hari.

10. Mekanisme koping

Biasanya klien menggunakan respon maldaptif yang ditandai dengan tingkah laku yang tidak terorganisir, marah-marah bila keinginannya tidak terpenuhi, memukul anggota keluarganya, dan merusak alat-alat rumah tangga.

11. Masalah psikologis dan lingkungan 
Biasanya klien merasa ditolak dan mengalami masalah interaksi dengan lingkungan

12. Pengetahuan

Biasanya klien dengan prilaku kekerasan kurang pengetahuan tentang penyakitnya,dan klien tidak mengetahui akibat dari putus obat dan fungsi Dari obat yang diminumnya. 


\section{BAB 3}

\section{TINJAUAN KASUS}

\subsection{Identitas Klien}

$\begin{array}{ll}\text { Inisial } & : \text { Tn. B } \\ \text { Jenis Kelamin } & : \text { Laki-laki } \\ \text { Umur } & : \text { 41 th } \\ \text { Status } & : \text { Bercerai } \\ \text { Tanggal pengkajian } & : \text { 28 Januari } 2022 \\ \text { Informan } & : \text { Status Pasien dan komunikasi dengan pasien }\end{array}$

\subsection{ALASAN MASUK RUMAH SAKIT :}

Alasan pasien masuk rumah sakit karena melakukan tindakan pembunuhan pada ayah kandungnya 2 bulan yang lalu, memukul kepala ibu nya, pasien sering marah marah dan melempar barang.

\subsection{FAKTOR PREDISPOSISI}

Klien sebelumnya pernah mengalami gangguan jiwa dan dirawat di RSJ Prof. Dr.M.Ildrem \pm 2 tahun yang lalu dan pulang ke rumah dalam keadaan tenang, dirumah klien kadang tidak rutin minum obat, dan tidak ada yang mau antar klien control dikarenakan jarak dari rumah ke RSJ yang lumayan jauh. Keluarga klien yang mengalami Riwayat gangguan jiwa adalah ayah klien. Masalah keperawatan : Resiko perilaku kekerasan

\subsection{FISIK}

Klien memiliki keluhan Nyeri pada rahang sebelah kanan, selalu timbul saat pasien selesai makan. Skala Nyeri 4. Saat dilakukan pemeriksaan tanda-tanda vital, ditemukan hasil TD : 122/81 mmHg;N:100x/I;S:36, $4^{\circ} \mathrm{C} ; \mathrm{P}: 22 x /$ i. klien memiliki tinggi badan $170 \mathrm{~cm}$ dan berat badan $68 \mathrm{~kg}$

Masalah Keperawatan: gangguan rasa nyaman : Nyeri

\subsection{PSIKOSOSIAL}

\subsubsection{Genogram}

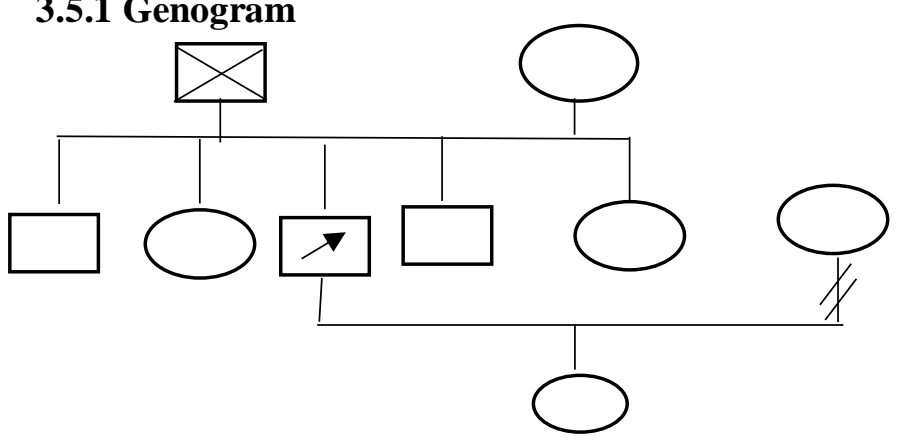


Penjelasan :

Klien merupakan anak ke 3 dari 5 bersaudara, klien sudah menikah dan memiliiki 1 anak perempuan, tapi dia ditinggal nikah oleh istrinya 10 th yang lalu karena dia memiliki gangguan jiwa dan tidak ada pekerjaan. Ayah klien meninggal 2 bulan yang lalu karena klien sendiri yang melakukannya

Keterangan :

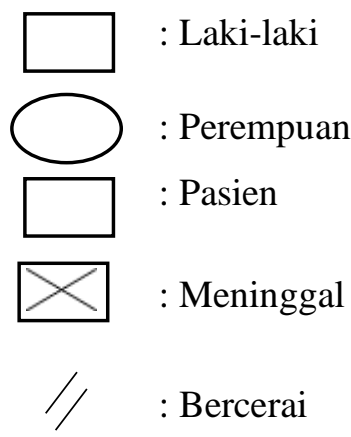

\subsubsection{Konsep Diri}

a. Gambaran Diri : Klien menyukai tubuhnya

b. Identitas : Klien merupakan anak ke 3 dari 5 bersaudara, klien sudah menikah dan memiliiki 1 anak perempuan, tapi dia ditinggal nikah oleh istrinya 10 th yang lalu karena dia memiliki gangguan jiwa dan tidak ada pekerjaan. Ayah klien meninggal 2 bulan yang lalu karena klien sendiri.

c. Peran : Klien berperan sebagai anak dari 5 bersaudara dan Klien berperan sebagai ayah dari anak 1

d. Ideal diri $\quad$ : Klien merasa dia tidak berguna lagi karena tidak ada yang mau menerima dirinya

e. Harga diri $\quad$ : Klien merasa bahwa saudaranya membenci dia dan istrinya meninggalkan dia karena dia sakit dan tidak memilki pekerjaan serta telah melakukan pembunuhan

Masalah Keperawatan: Gangguan Konsep Diri : Harga Diri Rendah

\subsubsection{Hubungan sosial}

a. Orang yang berarti : Keluarga

b. Peran serta dalam kegiatan kelompok/masyarakat :

Klien tidak mengikuti kegiatan apapun di lingkungan tempat tinggalnya. Namun di RSJ klien selalu ikut kegiatan atau aktvitas bersama, seperti senam 
atau kadang terapi aktivitas lainnya. Klien selalu bergabung dengan teman teman nya diruangan.

c. Hambatan dalam berhubungan dengan orang lain:

Emosi yang tidak bisa dikendalikan dan perasaan bersalah terhadap orang tua nya

Masalah Keperawatan: tidak ada masalah

\subsubsection{Spiritual}

a. Nilai dan Keyakinan : Klien Beragama Kristem dan meyakini agamnya

b. Kegiatan ibadah : Tidak pernah ibadah

Masalah Keperawatan : Defisit Spritual

\subsubsection{STATUS MENTAL}

Penampilan

Penjelasan :Klien berpenampilan rapi dan bersih

Pembicaraan

Penjelasan : Pasien berbicara dengan jelas dan tidak ada hambatan

Aktivitas motorik

Penjelasan :Klien tampak tegang saat beercerita tentang kejadian yang membuatnya masuk RSJ

Masalah Keperawatan : Risiko Perilaku kekerasan

Alam perasaan

Penjelasan $\quad$ : Klien merasa bahwa dia sudah tidak berguna dan tidak ada yang akan menerima dia lagi selain kakaknya yang mau menampung dia

Masalah keperawatan : Gangguan Konsep diri : harga diri rendah

Afek

Penjelasan

: Afek labil, Klien mudah marah dan emosi jika ada yang mengganggu atau tidaak mengikuti perintahnya

Masalah Keperawatan :Risiko Perilaku kekerasan

Interaksi selama wawancara

Penjelasan :tidak ada masalah, klien dapat menjawab dengan baik setiap pertanyaan yang diberikan

Masalah Keperawatan :tidak ada masalah

Persepsi : 
Penjelasan $\quad$ : Klien sering mendengar suara-suara aneh seperti suara anjing atau suara aneh lainnya dalam Bahasa daerahnya, isi suaranya seperti menantang dan mengejek, seperti "bereng", "mati kau" dan suara aneh lainnya

Masalah Keperawatan :halusinasi pendengaran

Proses Pikir

Penjelasan : Klien mampu menjawab pertanyaan dengan baik dan jelas

Pembicaraan/persevarasi

Penjelasan

: Tidak ada masalah dalam pembicaraan

Isi Pikir

Penjelasan

: Klien dapat mengendalikan isi pikirnya, tidak ada gangguan isi pikir atau waham

Tingkat Kesadaran

Penjelasan : kesadaran klien yaitu compos mentis, tidaak ada gangguan orientasi realita (orang, waktu, dan tempat).

Memori

Penjelasan $\quad$ : Klien mampu menceritakan kejadian di masa lalu dan yang baru terjadi.

Tingkat konsentrasi berhitung

Penjelasan : Klien mampu berkonsentrasi dalam perhitungan sederhana tanpa bantuan orang lain.

Kemampuan penilaian

Penjelasan

: Klien dapat membedakan hal yang baik dan yang buruk.

Daya tilik diri

Penjelasan

: Klien menyadari bahwa dirinya sakit, dia menyadari bahwa dirinya mudah marah dan gampang memukul orang.

\subsection{Mekanisme Koping}

Mekanisme koping klien adapattif, klien dapat berbicara dan berinteraksi serta kooperatif.

\subsection{Masalah Psikososial Dan Lingkungan}

Pasien tidak ikut kegiatan apapun dilingkungannya, pasien lebih sering menyendiri dikamar. Namun pasien selalu ikut dalam kegiatan di RSJ, seperti senam pagi atau kegiatan lainnya. 


\subsection{Pengetahuan Kurang Tentang Gangguan Jiwa}

Klien tidak paham bagaimana cara mengendalikan emosisnya,

\subsection{Aspek Medik}

Diagnosa Medik : Skizofrenia Paranoid

Terapi Medik : Rosperidone 2mg 2 x 1 dan Clozapinee 25 mg 1 X 1

\subsection{ANALISIS DATA}

\begin{tabular}{|l|l|c|}
\hline No & \multicolumn{1}{|c|}{ Data } & Masalah Keperawatan \\
\hline & $\begin{array}{l}\text { Subjektif : } \\
\text { Klien mengatakan pernah melempar } \\
\text { barang-barang yang ada dirumahnya, } \\
\text { pernah memukul keluarganya dan } \\
\text { membunuh ayahnya. Klien berkata suara } \\
\text { suara aneh menyuruhnya untuk membunuh } \\
\text { ayahnya. } \\
\text { Objektif: } \\
\text { Klien tampak tidak dapat menahan emosi } \\
\text { nya saat dia di ganggu atau saat teman } \\
\text { sekamarnya tidak mengikuti perintahnya }\end{array}$ \\
\hline $\mathbf{2}$ & $\begin{array}{l}\text { Subjektif : } \\
\text { Klien mengatakan mendengar suara suara } \\
\text { aneh seperti mengejek atau menyuruhnya } \\
\text { untuk memukul orang yang tidak dia } \\
\text { senangi. } \\
\text { Objektif : } \\
\text { Klien tampak bingung dan menutup telinga } \\
\text { dan gelisah }\end{array}$ \\
\hline
\end{tabular}




\begin{tabular}{|l|lr|c|}
\hline 3 & \multicolumn{2}{|l|}{ Subjektif : } & Gangguan Konsep Diri \\
Klien mengatakan dibuang $\quad$ oleh & : Harga diri rendah \\
keluarganya dan merasa minder & dengan & \\
orang lain karena dia memiliki sifat & \\
temperamen, sehingga dia berkata orang & \\
orang pun menjauhinya & \\
Objektif : & \\
Klien tampak malu dan gelisah, dan tanpak & \\
sedih saat di kaji serta menundukkan kepala & \\
\hline
\end{tabular}

\subsection{DAFTAR MASALAH KEPERAWATAN}

a. Risiko Perilaku Kekerasan

b. Gangguan Persepsi Sensori :Halusinasi Pendengaran

c. Gangguan Konsep Diri : Harga Diri Rendah

\subsection{POHON MASALAH}

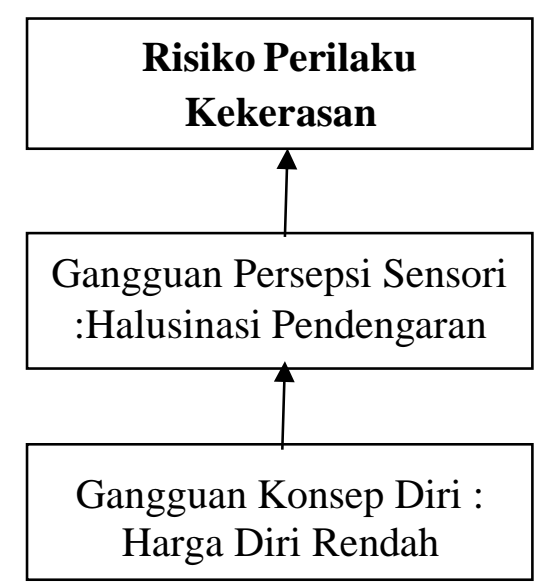

\subsection{DAFTAR DIAGNOSIS KEPERAWATAN}

1. Risiko Perilaku Kekerasan

2. Halusinasi

3. Harga Diri Rendah 


\subsection{IAÉbERAYHAUSI KEPERAWATAN}

\begin{tabular}{|c|c|c|c|}
\hline \multirow[t]{5}{*}{$\begin{array}{l}\text { Risiko } \\
\text { Prilaku } \\
\text { Kekerasan }\end{array}$} & $\begin{array}{l}\text { Klien dapat membina } \\
\text { hubungan saling } \\
\text { percaya }\end{array}$ & $\begin{array}{l}\text { Ketikadi evaluasi } \\
\text { Klien mau } \\
\text { membalas salam, } \\
\text { berjabat tangan, } \\
\text { menyebutkan nama, } \\
\text { tersenyum, ada } \\
\text { kontak mata, serta } \\
\text { menyediakan waktu } \\
\text { untuk kunjungan } \\
\text { berikutnya }\end{array}$ & 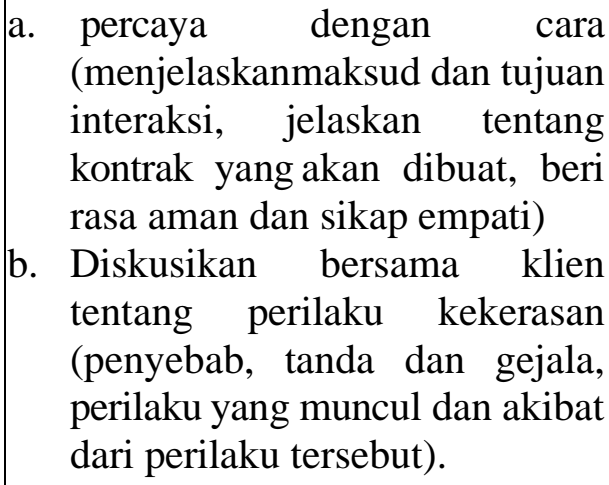 \\
\hline & $\begin{array}{l}\text { Klien dapat } \\
\text { mengendalikan } \\
\text { perilaku kekerasan } \\
\text { dengan cara relaksasi } \\
\text { nafas dalamdan } \\
\text { pukul bantal kasur }\end{array}$ & $\begin{array}{l}\text { Klien mampu } \\
\text { menyebutkan dan } \\
\text { menredemonstrasi } \\
\text { kan cara } \\
\text { mengontrol perilaku } \\
\text { kekerasandengan } \\
\text { cara relaksasi nafas } \\
\text { dalam dan pukul } \\
\text { bantal }\end{array}$ & $\begin{array}{l}\text { Sp } 1 \\
\text { Latih klien melakukan } \\
\text { cara mengontrol } \\
\text { Kemarahan: } \\
\text { a. Ajarkan tehnik relaksasi } \\
\quad \text { nafas dalam } \\
\text { b. Pukul bantal }\end{array}$ \\
\hline & $\begin{array}{l}\text { Klien dapat } \\
\text { mengendalikan } \\
\text { perilaku kekerasan } \\
\text { dengan minum obat } \\
\text { secara teratur }\end{array}$ & $\begin{array}{l}\text { Klien mampu } \\
\text { mengendalikan } \\
\text { perilaku kekerasan } \\
\text { dengan minum obat }\end{array}$ & 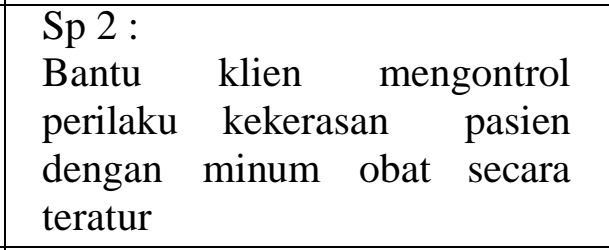 \\
\hline & $\begin{array}{l}\text { klien paham dan } \\
\text { mampu } \\
\text { mengendalikan } \\
\text { risiko perilaku } \\
\text { kekerasan dengan } \\
\text { cara berbicara } \\
\text { dengan baik }\end{array}$ & $\begin{array}{l}\text { Klien paham dan } \\
\text { mampu } \\
\text { menyampaikan } \\
\text { amarah } \\
\quad \text { dengan cara } \\
\text { berbicara } \\
\text { dengan baik }\end{array}$ & $\begin{array}{l}\text { Lakukan SP } 3 \\
\text { pasien risiko perilaku } \\
\text { kekerasan: } \\
\text { 1. Ajarkan kepada klien bicara } \\
\text { yang baik bila sedang marah. } \\
\text { Ada tigacara: } \\
\text { 2. Meminta dengan baik tanpa } \\
\text { marah } \\
\text { 3. Menolak dengan baik } \\
\text { 4. Mengungkapkan perasaan } \\
\text { kesal }\end{array}$ \\
\hline & $\begin{array}{l}\text { Klien paham dan } \\
\text { mampu } \\
\text { mengendalikan } \\
\text { risiko perilaku } \\
\text { kekerasan dengan } \\
\text { cara mempraktikan } \\
\text { cara spiritual } \\
\text { (beribadah) }\end{array}$ & $\begin{array}{l}\text { Klien paham dan } \\
\text { mampu } \\
\text { mengendalikan } \\
\text { risiko perilaku } \\
\text { kekerasan dengan } \\
\text { cara beribadah }\end{array}$ & $\begin{array}{l}\text { Lakukan SP } 4 \\
\text { pasien risiko perilaku kekerasan } \\
: \\
\text { Diskusikan bersama kliencara } \\
\text { mengendalik an risiko perilaku } \\
\text { kekerasandengan cara beribadah. }\end{array}$ \\
\hline $\begin{array}{l}\text { Halusinasi } \\
\text { Pendengaran }\end{array}$ & $\begin{array}{l}\text { Klien paham dan } \\
\text { mampu } \\
\text { mengendalikan } \\
\text { halusinasi dengan }\end{array}$ & $\begin{array}{l}\text { Klien paham dan } \\
\text { mampu } \\
\text { mengendalikan } \\
\text { halusinasi dengan }\end{array}$ & $\begin{array}{l}\text { 1. Diskusikan bersama klien } \\
\text { tentang halusinasi (isi, } \\
\text { frekuensi, waktu terjadi, } \\
\text { situasi pencetus, perasaan, } \\
\text { dan respon halusinasi) }\end{array}$ \\
\hline
\end{tabular}




\begin{tabular}{|c|c|c|c|}
\hline & $\begin{array}{l}\text { cara mempraktikan } \\
\text { cara menghardik }\end{array}$ & $\begin{array}{l}\text { cara mempraktikan } \\
\text { cara menghardik }\end{array}$ & \\
\hline & $\begin{array}{l}\text { Klien paham dan } \\
\text { mampu } \\
\text { mengendalikan } \\
\text { halusinasi dengan } \\
\text { cara mempraktikan } \\
\text { cara menghardik }\end{array}$ & $\begin{array}{l}\text { Klien paham dan } \\
\text { mampu } \\
\text { mengendalikan } \\
\text { halusinasi dengan } \\
\text { cara mempraktikan } \\
\text { cara menghardik }\end{array}$ & $\begin{array}{l}\text { Sp } 1 \\
\text { Latih klien cara menghardik }\end{array}$ \\
\hline & $\begin{array}{l}\text { Klien paham dan } \\
\text { mau minum obat } \\
\text { secara teratur }\end{array}$ & $\begin{array}{l}\text { Klien paham dan } \\
\text { mau minum obat } \\
\text { secara teratur }\end{array}$ & $\begin{array}{l}\text { Sp } 2 \\
\text { Latih klien minun obat secara } \\
\text { teratur }\end{array}$ \\
\hline & $\begin{array}{l}\text { Klien paham dan } \\
\text { mampu } \\
\text { mengendalikan } \\
\text { halusinasi dengan } \\
\text { cara bercakap-cakap } \\
\text { dengan orang lain }\end{array}$ & $\begin{array}{l}\text { Klien paham dan } \\
\text { mampu } \\
\text { mengendalikan } \\
\text { halusinasi dengan } \\
\text { cara bercakap- } \\
\text { cakap dengan orang } \\
\text { lain }\end{array}$ & $\begin{array}{l}\text { Sp } 3 \\
\text { Latih klien bercakap-cakap } \\
\text { dengan orang lain }\end{array}$ \\
\hline & $\begin{array}{l}\text { Klien paham dan } \\
\text { mampu } \\
\text { mengendalikan } \\
\text { halusinasi dengan } \\
\text { cara melakukan } \\
\text { kegiatan terjadwal }\end{array}$ & $\begin{array}{l}\text { Klien paham dan } \\
\text { mampu } \\
\text { mengendalikan } \\
\text { halusinasi dengan } \\
\text { cara melakukan } \\
\text { kegiatan terjadwal }\end{array}$ & $\begin{array}{l}\text { Sp } 4 \\
\text { Latih klien melakukan kegiatan } \\
\text { terjadwal }\end{array}$ \\
\hline \multirow[t]{4}{*}{$\begin{array}{l}\text { Harga Diri } \\
\text { Rendah } \\
\text { Kronik }\end{array}$} & $\begin{array}{l}\text { Klien paham dan } \\
\text { mampu } \\
\text { mengindentifikasi } \\
\text { kemampuan positif } \\
\text { yang dimiliki }\end{array}$ & $\begin{array}{l}\text { Klien paham dan } \\
\text { mampu } \\
\text { mengindentifikasi } \\
\text { kemampuan positif } \\
\text { yang dimiliki }\end{array}$ & $\begin{array}{l}\text { Sp 1 } \\
\text { Diskusikan bersama klien } \\
\text { tentang kemampuan positif } \\
\text { yang dimiliki }\end{array}$ \\
\hline & $\begin{array}{l}\text { Klien paham dan } \\
\text { mampu menilai } \\
\text { kemampuan yang } \\
\text { dapat digunakan }\end{array}$ & $\begin{array}{l}\text { Klien paham dan } \\
\text { mampu menilai } \\
\text { kemampuan yang } \\
\text { dapat digunakan }\end{array}$ & $\begin{array}{l}\text { Sp } 2 \\
\text { 1. Bantu klien menilai } \\
\text { kemampuan yang dapat } \\
\text { digunakan } \\
\text { 2. Bantu klien menetapkan } \\
\text { kemampuan yang dapat } \\
\text { digunakan } \\
\text { Melatih kegiatan sesuai } \\
\text { kemampuan yang dipilih } 1\end{array}$ \\
\hline & $\begin{array}{l}\text { Klien paham dan } \\
\text { mampu melatih } \\
\text { kegiatan yang dapat } \\
\text { digunakan }\end{array}$ & $\begin{array}{l}\text { Klien paham dan } \\
\text { mampu melatih } \\
\text { kegiatan yang dapat } \\
\text { digunakan }\end{array}$ & $\begin{array}{l}\text { Sp } 3 \\
\text { Melatih kegiatan sesuai } \\
\text { kemampuan yang dipilih } 2\end{array}$ \\
\hline & $\begin{array}{l}\text { Klien paham dan } \\
\text { mampu melatih } \\
\text { kegiatan yang dapat } \\
\text { digunakan }\end{array}$ & $\begin{array}{l}\text { Klien paham dan } \\
\text { mampu melatih } \\
\text { kegiatan yang dapat } \\
\text { digunakan }\end{array}$ & $\begin{array}{l}\text { Sp } 4 \\
\text { Melatih kegiatan sesuai } \\
\text { kemampuan yang dipilih } 3\end{array}$ \\
\hline
\end{tabular}




\subsection{IMPLEMENTASI DAN EVALUASI KEPERAWATAN}

\begin{tabular}{|c|c|c|}
\hline Hari/tgl & Implementasi & Evaluasi \\
\hline $\begin{array}{l}\text { Jumat, } 28 \\
\text { Januari } \\
2022 \\
14.30\end{array}$ & $\begin{array}{l}\text { 1. Data : } \\
\text { Tanda dan gejala : mudah marah- marah, } \\
\text { mudah tersinggung,tatapansinis, ,suka } \\
\text { menyendiri, merasa tidak dihargai } \\
\text { 2. Diagnosa Keperawatan Risiko } \\
\text { Perilaku KekerasanHarga Diri } \\
\text { Rendah } \\
\text { 3. Tindakan keperawatan: } \\
\text { Sp 1 Risiko Perilaku Kekerasan: } \\
\text { - } \text { Mengidentifikasi penyebab risiko } \\
\text { perilaku kekerasan yaitu jika kemauan } \\
\text { klien tidak dituruti } \\
\text { Mengidentifikasi tanda dan gejalarisiko } \\
\text { perilaku kekerasan yaitu klien marah, } \\
\text { mengamuk tanpa jelas, merusak barang- } \\
\text { barang, dan cenderung melukai orang } \\
\text { lain } \\
\text { Menyebutkan cara mengontrol risiko } \\
\text { perilaku kekerasan adalah dengan latihan } \\
\text { fisik 1 : tarik napasdalam latihan fisik } 2 \text { : } \\
\text { pukul kasurbantal } \\
\text { Membantu klien latihan tariknapas } \\
\text { dalam dan pukul kasurbantal. } \\
\text { 4. RTL: } \\
\text { Sp2 Risiko Perilaku Kekerasan: } \\
\text { - Mengontrolrisiko perilaku kekerasan } \\
\text { dengan minum obatsecara teratur }\end{array}$ & 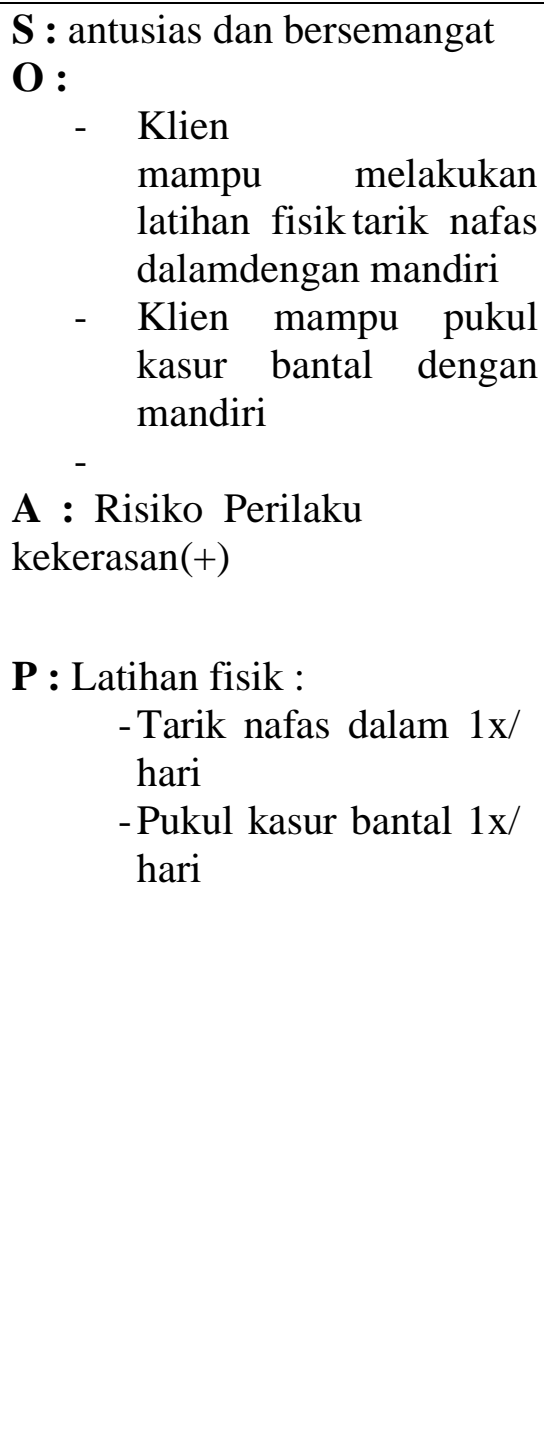 \\
\hline
\end{tabular}




\begin{tabular}{|c|c|c|}
\hline $\begin{array}{l}\text { Sabtu } 29 \\
\text { Januari } \\
2022 \\
14.30 \text { WIB }\end{array}$ & $\begin{array}{l}\text { 1. Data : } \\
\text { Tanda dan gejala : mudah marah- marah, } \\
\text { mudah tersinggung,tatapansinis, merasa } \\
\text { tidak dihargai Kemampuan : berjualan } \\
\text { depan rumah } \\
\text { 2. Diagnosa Keperawatan Risiko } \\
\text { Perilaku Kekerasan } \\
\text { 3. Tindakan keperawatan: } \\
\text { Sp } 2 \text { Risiko Perilaku Kekerasan } \\
\text { 1. Mengevaluasi kemampuan klien } \\
\text { untuk tarik nafas dalamdan pukul } \\
\text { kasur bantal } \\
\text { 2. Memberikan informasi tentang } \\
\quad \text { penggunaan obat } \\
\text { RTL: } \\
\text { Sp } 3 \text { Risiko Perilaku Kekerasan } \\
\text { - Komunikasi secara } \\
\text { verbal:Asertif/bicara baik-baik. }\end{array}$ & 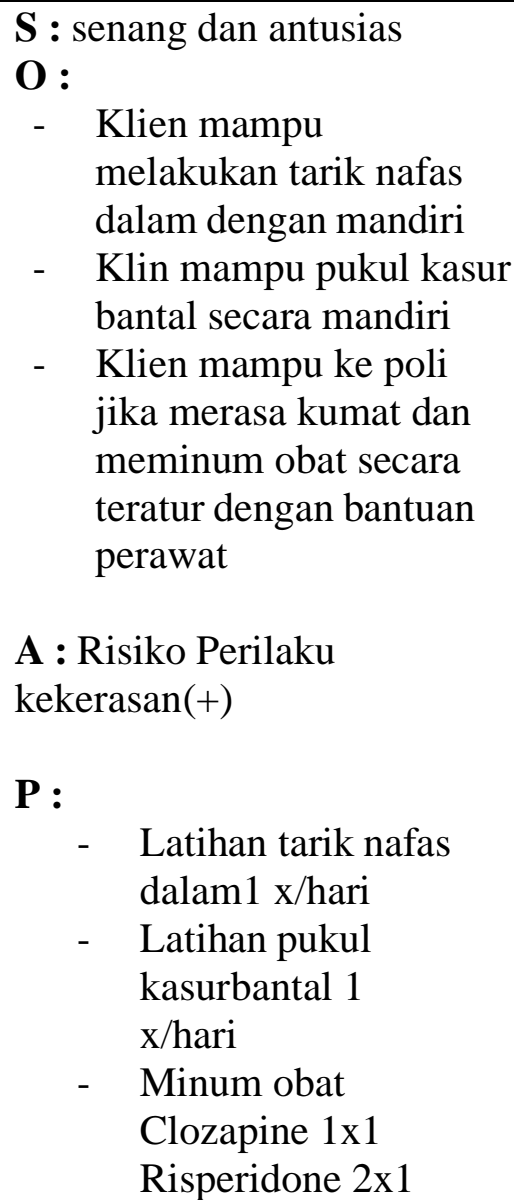 \\
\hline
\end{tabular}




\begin{tabular}{|c|c|c|}
\hline $\begin{array}{l}\text { Rabu, } 2 \\
\text { Februari } \\
2022\end{array}$ & $\begin{array}{l}\text { 1. Data: } \\
\text { Tanda dan gejala : mudah marah- marah, } \\
\text { mudah tersinggung,tatapansinis, merasa } \\
\text { tidak dihargai Kemampuan : berjualan } \\
\text { depan rumah } \\
\text { 2. Diagnosa Keperawatan Risiko } \\
\text { Perilaku Kekerasan } \\
\text { 3. Tindakan keperawatan: } \\
\text { Sp } 3 \text { Risiko Perilaku Kekerasan } \\
\text { 1. Mengevaluasi pengetahuan klien } \\
\quad \text { tentang obat } \\
\text { 2. Komunikasi secara verbal : } \\
\quad \text { Asertif/bicara baik-baik } \\
\text { RTL: } \\
\text { Sp } 4 \text { Risiko Perilaku Kekerasan } \\
\text { Spiritual. }\end{array}$ & 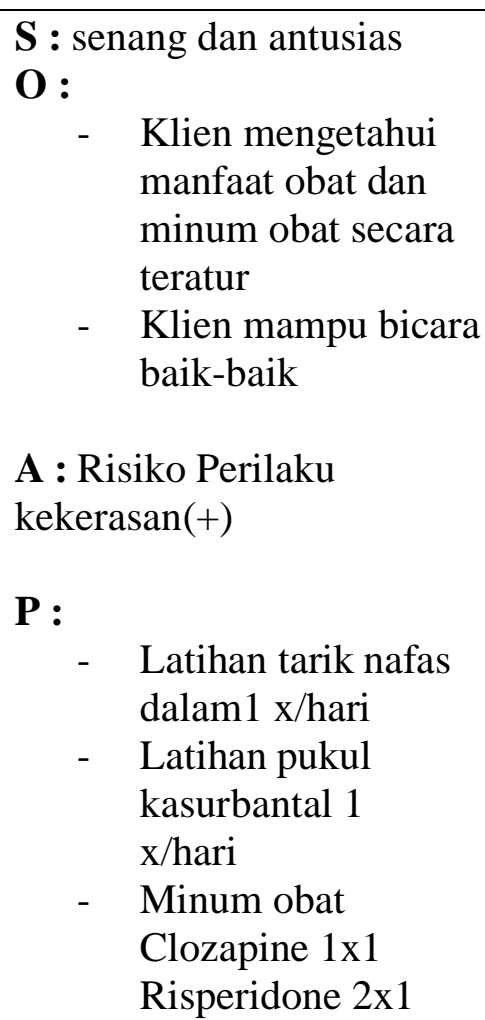 \\
\hline $\begin{array}{l}\text { Kamis, } 3 \\
\text { Februari } \\
2022\end{array}$ & $\begin{array}{l}\text { 1. Data : } \\
\text { Tanda dan gejala : mudah marah- marah, } \\
\text { mudah tersinggung,tatapansinis, merasa } \\
\text { tidak dihargai Kemampuan : berjualan } \\
\text { depan rumah } \\
\text { 2. Diagnosa Keperawatan Risiko } \\
\text { Perilaku Kekerasan } \\
\text { 3. Tindakan keperawatan: } \\
\text { Sp 4 Risiko Perilaku Kekerasan } \\
\text { 1. Mengevaluasi cara bicara klien } \\
\text { 2. Melatih spiritual } \\
\text { RTL: } \\
\text { Evaluasi Sp1-Sp4 }\end{array}$ & $\begin{array}{ll}\text { S : } & \text { senang dan antusias } \\
\text { O : } & \text { Klien belum mampu } \\
& \text { berdoa } \\
\text { A : } & \text { Risiko Perilaku } \\
\text { kekerasan(+) } & \\
\text { P : } & \\
\text { - } & \text { Latihan tarik nafas } \\
& \text { dalam1 x/hari } \\
- & \text { Latihan pukul } \\
& \text { kasurbantal } 1 \\
& \text { X/hari } \\
- & \text { Minum obat } \\
& \text { Clozapine } 1 \times 1 \\
& \text { Risperidone } 2 \times 1 \\
- & \text { Berdoa } 3 \times 1\end{array}$ \\
\hline
\end{tabular}




\begin{tabular}{|c|c|c|}
\hline $\begin{array}{l}\text { Jumat, } 4 \\
\text { Februari } \\
2022\end{array}$ & $\begin{aligned} & \text { 1. } \text { Data : } \\
& \text { Tanda dan gejala : mudah marah- } \\
& \text { marah, mudah tersinggung,tatapan } \\
& \text { sinis, merasa tidak dihargai } \\
& \text { Kemampuan : berjualan depan rumah } \\
& \text { 2. } \text { Diagnosa Keperawatan Risiko } \\
& \text { Perilaku Kekerasan } \\
& \text { 3. } \text { Tindakan keperawatan: } \\
& \text { Sp Risiko Perilaku Kekerasan } \\
& \text { Evaluasi Sp1- Sp4 }\end{aligned}$ & 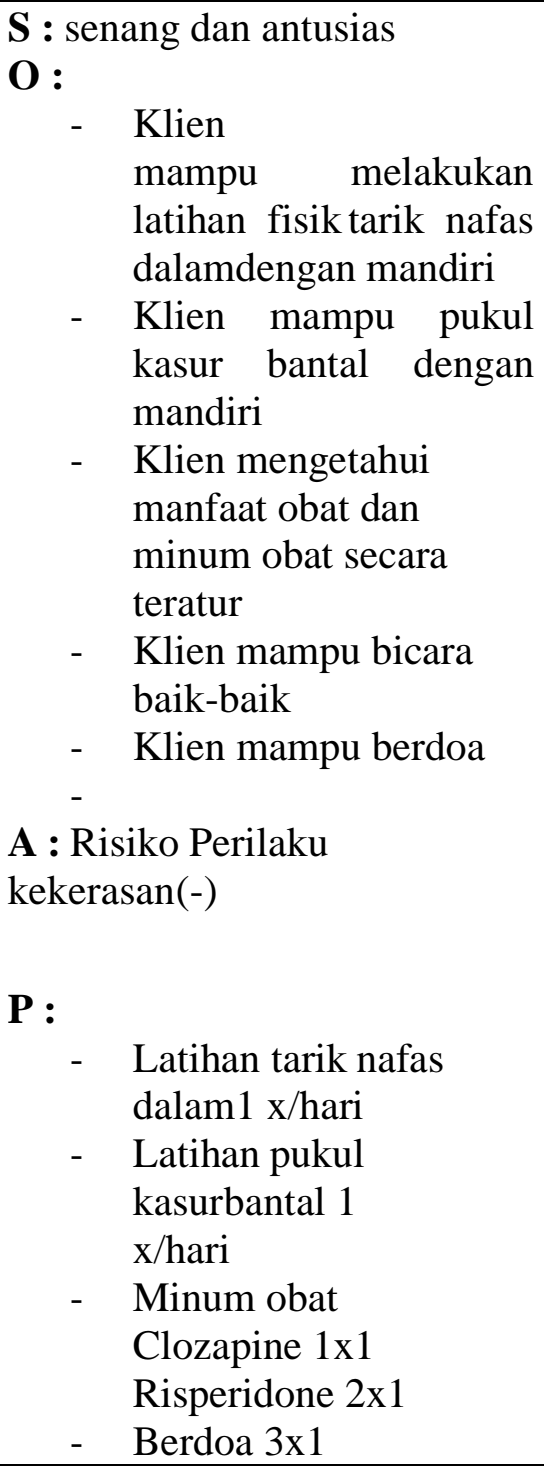 \\
\hline
\end{tabular}




\begin{tabular}{|c|c|c|}
\hline \begin{tabular}{|l} 
Senin, 7 \\
Februari \\
2022
\end{tabular} & $\begin{array}{l}\text { 1. Data: } \\
\text { Tanda dan gejala :Berbicara sendiri, } \\
\text { Mendengar suara-suara, Menutup telinga } \\
\text { 2. Diagnosa Keperawatan : Halusinasi } \\
\text { pendengaran } \\
\text { 3. Tindakan keperawatan } \\
\text { Sp 1 Halusinasi pendengaran } \\
\text { 1. Mengidentifikasi isi, frekuensi, waktu } \\
\text { terjadi, situasi pencetus, perasaan dan } \\
\text { respon halusiasi } \\
\text { 2. Melatih cara Menghardik } \\
\text { 4. RTL: } \\
\text { Sp 2 Halusinasi Pedengaran } \\
\text { 1. Minum obat secara teratur }\end{array}$ & $\begin{array}{l}\text { S: } \\
\text { pasien mengatakan masih } \\
\text { mendengar suara-suara aneh } \\
\text { yang berbisik seperti mengejek } \\
\text { dan menyuruh nya untuk } \\
\text { membunuh ayahnya, dan } \\
\text { melihat bayangan seperti } \\
\text { matahari yang berbicara } \\
\text { O: } \\
\text { klien tampak berbicara tidak } \\
\text { jelas, klien tampak gelisah dan } \\
\text { ketakutan } \\
\text { A:Halusinasi Pendengaran }(+) \\
\text { P: } \\
\text {-Menghardik } 3 \times 1\end{array}$ \\
\hline $\begin{array}{l}\text { Selasa, } 8 \\
\text { Februari } \\
2022\end{array}$ & $\begin{array}{l}\text { Data: } \\
\text { 1. Tanda dan gejala :Berbicara sendiri, } \\
\text { Mendengar suara-suara, Menutup telinga } \\
\text { 2. Diagnosa Keperawatan : Halusinasi } \\
\text { pendengaran } \\
\text { Tindakan keperawatan } \\
\text { Sp } 2 \text { Halusinasi pendengaran } \\
\text { 1. Minum Obat teratur } \\
\text { 4. RTL: } \\
\text { Sp } 3 \text { Halusinasi Pedengaran } \\
\text { 1. Bercakap-cakap dengan orang lain }\end{array}$ & $\begin{array}{l}\text { S: } \\
\text { pasien mengatakan masih } \\
\text { mendengar suara-suara yang } \\
\text { berkata "bereng, apa kau, bunuh } \\
\text { bapakmu, bapakmu jahat", dan } \\
\text { melihat bayangan seperti } \\
\text { binatang atau matahari yang } \\
\text { berbicara kepadanya } \\
\text { O: } \\
\text { klien tampak berbicara ngaur, } \\
\text { klien tampak ketakutan } \\
\text { klien mampu minum obat secara } \\
\text { teratur } \\
\text { A:Halusinasi Pendengaran (+) } \\
\text { P: } \\
\text {-Menghardik } 3 \times 1 \\
\text {-Minum obat } 2 \times 1 \\
\text { Risperidone } 2 \times 1 \\
\text { Clozapine 1x1 }\end{array}$ \\
\hline
\end{tabular}




\begin{tabular}{|c|c|c|}
\hline $\begin{array}{l}\text { Rabu, } 9 \\
\text { Februari } \\
2022\end{array}$ & $\begin{array}{l}\text { 1. Data: } \\
\text { Tanda dan gejala :Berbicara sendiri, } \\
\text { Mendengar suara-suara, Menutup telinga } \\
\text { 2. Diagnosa Keperawatan : Halusinasi } \\
\text { pendengaran } \\
\text { 3. Tindakan keperawatan } \\
\text { Sp } 3 \text { Halusinasi pendengaran } \\
\text { 1. Evaluasi pengetahuan dan kepatuhan } \\
\text { minum obat } \\
\text { 2. Bercakap-cakap dengan orang lain } \\
\text { 4. RTL: } \\
\text { Sp4 halusinasi pendengaran } \\
\text { 1. Melakukan Kegiatan terjadwal }\end{array}$ & $\begin{array}{l}\text { S: } \\
\text { pasien mengatakan suara suara } \\
\text { mulai berkurang, } \\
\text { O: } \quad \text { Klien mengetahui } \\
\quad \text { manfaat obat } \\
\quad \text { Klien mampu } \\
\quad \text { bercakap-cakap dengan } \\
\text { orang lain } \\
\text { A:Halusinasi Pendengaran }(+) \\
\text { P : } \\
\text {-Menghardik } 3 \times 1 \\
\text {-Minum obat } 2 \times 1 \\
\text { Risperidone } 2 \times 1 \\
\text { Clozapine } 1 \times 1\end{array}$ \\
\hline $\begin{array}{l}\text { Senin, } 14 \\
\text { Februari } \\
2022\end{array}$ & $\begin{array}{l}\text { 1. Data: } \\
\text { Tanda dan gejala :Berbicara sendiri, } \\
\text { Mendengar suara-suara, Menutup telinga } \\
\text { 2. Diagnosa Keperawatan : Halusinasi } \\
\text { pendengaran } \\
\text { 3. Tindakan keperawatan } \\
\text { Sp } 4 \text { Halusinasi pendengaran } \\
\text { 1. Melakukan Kegiatan terjadwal } \\
\text { 4. RTL: } \\
\text { Evaluasi Sp1-Sp4 }\end{array}$ & $\begin{array}{l}\text { S: } \\
\text { Klien merasa senang } \\
\text { O: } \\
\text { Klien melakukan kegiatan } \\
\text { terjadwal } \\
\text { A:Halusinasi Pendengaran (+) } \\
\text { P : } \\
\text {-Menghardik } 3 \times 1 \\
\text {-Minum obat } 2 \times 1 \\
\text { Risperidone } 2 \times 1 \\
\text { Clozapine } 1 \times 1\end{array}$ \\
\hline
\end{tabular}




\begin{tabular}{|c|c|c|}
\hline $\begin{array}{l}\text { Selasa, } \\
15 \\
\text { Februari } \\
2022\end{array}$ & $\begin{array}{l}\text { 1. Data } \\
\text { Tanda dan gejala : Klien tampak malu dan } \\
\text { gelisah, dan tanpak sedih saat di kaji serta } \\
\text { menundukkan kepala } \\
\text { 2. Diagnosa keperawatan : Harga diri rendah } \\
\text { 3. Tindakan keperawatan } \\
\text { Sp 1 HDR } \\
\text { i. Mengidentifikasi kemampuan dan aspek } \\
\text { positif yang dimiliki } \\
\text { 4. RTL: } \\
\text { Sp } 2 \text { HDR } \\
\text { 1. Menilai kemamampuan yang dapat di } \\
\text { gunakan } \\
\text { 2. Menetapkan/memilih kegiatan sesuai } \\
\text { kemampuan } \\
\text { 3. Melatih kegiatan sesuai kemampuan yang } \\
\text { dipilih } 1\end{array}$ & $\begin{array}{l}\text { S : } \\
\text { Klien mengatakan masih gelisah } \\
\text { dan malu } \\
\text { O: } \\
- \text { Klien mampu memilih } \\
\text { kemampuan rang } \\
\text { dimiliki(Membersihkan tempat } \\
\text { tidur, mencuci piring, Menyapu) } \\
\text {-Klien tampak menundukan } \\
\text { kepala } \\
\text { A: } \\
\text { HDR (+) } \\
\text { P: } \\
\text {-Membersihkan tempat tidur }\end{array}$ \\
\hline $\begin{array}{l}\text { Rabu, } 16 \\
\text { Februari } \\
2022\end{array}$ & $\begin{array}{l}\text { 1. Data } \\
\text { Tanda dan gejala : Klien tampak malu dan } \\
\text { gelisah, dan tanpak sedih saat di kaji serta } \\
\text { menundukkan kepala } \\
\text { 2. Diagnosa keperawatan : Harga diri rendah } \\
\text { 3. Tindakan keperawatan } \\
\text { Sp } 2 \text { HDR } \\
\text { 1. Menilai kemamampuan yang dapat di } \\
\text { gunakan } \\
\text { 2. Menetapkan/memilih kegiatan sesuai } \\
\text { kemampuan } \\
\text { 3. Melatih kegiatan sesuai kemampuan yang } \\
\text { dipilih } 1 \\
\text { 4. RTL: } \\
\text { Sp } 2 \text { HDR } \\
\text { 1. Melatih kegiatan sesuai kemampuan yang } \\
\text { dipilih } 2\end{array}$ & $\begin{array}{l}\text { S : } \\
\text { Klien mengatakan masih gelisah } \\
\text { O: } \\
\text {-Klien mampu Membersihkan } \\
\text { tempat tidur } \\
\text { A: } \\
\text { HDR (+) } \\
\text { P: } \\
\text {-Membersihkan tempat tidur }\end{array}$ \\
\hline
\end{tabular}




\begin{tabular}{|c|c|c|}
\hline $\begin{array}{l}\text { Kamis, } \\
17 \\
\text { Februari } \\
2022\end{array}$ & $\begin{array}{l}\text { 1. Data } \\
\text { Tanda dan gejala : Klien tampak malu dan } \\
\text { gelisah, dan tanpak sedih saat di kaji serta } \\
\text { menundukkan kepala } \\
\text { 2. Diagnosa keperawatan : Harga diri rendah } \\
\text { 3. Tindakan keperawatan } \\
\text { Sp } \mathbf{3} \text { HDR } \\
\text { 1. Melatih kegiatan sesuai kemampuan yang } \\
\text { dipilih } 2 \\
\text { 4. RTL: } \\
\text { Sp } 4 \text { HDR } \\
\text { 1. Melatih kegiatan sesuai kemampuan yang } \\
\text { dipilih } 3\end{array}$ & $\begin{array}{l}\text { S : } \\
\text { Klien mengatakan senang } \\
\text { O: } \\
\text {-Klien mampu mencuci piring } \\
\text { A: } \\
\text { HDR (+) } \\
\text { P: } \\
\text {-Membersihkan tempat tidur } \\
\text {-Mencuci piring 1x1 hari }\end{array}$ \\
\hline $\begin{array}{l}\text { Jumat, } \\
18 \\
\text { Februari } \\
2022\end{array}$ & $\begin{array}{l}\text { 1. Data } \\
\text { Tanda dan gejala : Klien tampak malu dan } \\
\text { gelisah, dan tanpak sedih saat di kaji serta } \\
\text { menundukkan kepala } \\
\text { 2. Diagnosa keperawatan : Harga diri rendah } \\
\text { 3. Tindakan keperawatan } \\
\text { Sp } 4 \text { HDR } \\
\text { 4. Melatih kegiatan sesuai kemampuan yang } \\
\text { dipilih } 3 \\
\text { 4. RTL: } \\
\text { Evaluasi Sp1-Sp4 }\end{array}$ & $\begin{array}{l}\text { S : } \\
\text { Klien mengatakan senang } \\
\text { O: } \\
\text {-Klien mampu menyapu } \\
\text { A: } \\
\text { HDR (+) } \\
\text { P: } \\
\text {-Membersihkan tempat tidur } \\
\text {-Mencuci piring 1x1/hari } \\
\text {-Menyapu 2x1/hari }\end{array}$ \\
\hline
\end{tabular}




\section{BAB 4 \\ PEMBAHASAN}

Setelah penulis melaksanakan asuhan keperawatan kepada Tn.B dengan Risiko Perilaku Kekerasan di Rumah Sakit Jiwa Prof M.Illdrem , maka penulis pada BAB ini akan membahasan kesenjangan antara teoritis dengan tinjauan kasus. Risiko perilaku kekerasan terhadap orang lain adalah rentan melakukan perilaku yang menunjukkan dapat membahayakan orang lain secara fisik dan emosional (NandaI, 2018). Sujarwo dan Livana (2019) mengungkapkan bahwa pada klien dengan masalah risiko perilaku kekerasan dapat dilakukan rencana tindakan keperawatan melalui strategi pelaksanaan meliputi mengendalikan perilaku kekerasan secara fisik (dilakukan dengan napas dalam dan pukul bantal), melalui obat dengan prinsip lima benar obat secara teratur, secara verbal yaitu dengan mengungkapkan, meminta dan menolak dengan baik, dan dengan cara spiritual seperti berdoa dan beribadah. Pembahasan dimulai melalui tahapan proses keperawatan yaitu pengkajian, diagnosa keperawatan, perencanaan, pelaksanaan dan evaluasi.

\subsection{Tahap Pengkajian}

Selama pengkajian dilakukan pengumpulan data dari beberapa sumber yaitu dari pasien dan perawat di RSJ, Mahasiswa mendapat sedikit kesulitan dalam menyimpulkan data kerena keluarga pasien jarang mengkunjungi pasien dikarenakan COVID-19 sehingga dibatasi pengunjung di RSJ. Maka mahasiwa melakukan pendekatan pada pasien melalui komunikasi terapautik yang lebih terbuka membantu pasien untuk memecahkan perasaannya dan juga melakukan observasi kepada pasien.

Adapun upaya tersebut yaitu :

a. Melakukan pendekatan dan membina hubungan saling percaya diri pada pasien agar pasien lebih terbuka dan lebih percaya dengan menggunakan perasaan.

b. Mengadakan pengkajian pasien dengan wawancara

c. Mengadakan pengkajian dengan membaca status pasien, melihat buku rawatan serta bertanya kepada pegawai di ruangan Sorik Merapi 
Dalam pengkajian yang dilakukan, ditemukan kesenjangan dimana Tn.B sangat mudah marah, emosinya mudah terpancing dan ada beberapa teman sekamarnya yang dia pukul hingga menyebabkan terjadinya pendarahan, Risiko perilaku kekerasan terhadap orang lain adalah rentan melakukan perilaku yang menunjukkan dapat membahayakan orang lain secara fisik dan emosional (Nanda-I, 2018). Menurut Budi Anna Keliat (2019) Diagnose keperawatan yang yang menjadi penyebab RPK adalah Waham, Halusinasi, Berencana bunuh diri, Gangguan Konsep diri (Harga diri rendah) dan Isolasi social. Sebelum masuk RSJ, Tn.B telah melakukan kekerasan pada ayah dan ibunya. Dalam pengkajian juga ditemukan bahwa Tn.B sering mendengar suara suara aneh yang berbisik dengan Bahasa daerahnya seperti "bereng, ritik, " bahkan sering berkata agar Tn.B memukul. Hal itu membuat Tn.B merasa tidak berguna, merasa bahwa dirinya hanya membawa masalah saja. Bahkan dia tidak tau akan tinggal dimana setelah keluar dari RSJ.

Tindakan keperawatan terapi generalis yang dilakukan padaa Tn.B adalah strategi pelaksanaanpertama hingga strategi pelaksanaankeempat pada Risiko Perilaku kekerasan,. Strategi pelaksanaanI yaitu latian mengontrol perilaku kekerasan dengan Latihan fisik 1: Tarik nafas dalam, kemudian diteruskan dengan Latihan fisik 2 : pukul Kasur bantal. Strategi pelaksanaan kedua adalah minum obat secara teratur. Strategi pelaksanaan ketiga adalah melatih komunikasi asertif atau berbicara baik baik. Strategi pelaksanaan keempat adalah spiritual.

Setelah diterapkan keempat strategi pelaksanaan pada risiko perilaku kekerasan, kemudian dilanjutkan dengan strategi pelaksanaan pada halusinasi pendengaran. Strategi pertama meliputi mengidentifikasi isi, frekuensi, waktu terjadi, situasi pencetus, perasaan dan respon halusinasi serta cara mengontrol halusinasi dengan menghardik. Strategi pelaksanaan kedua yang dilakukan pada Tn.B adalah minum obat secara teratur. Setelah itu dilanjutkan dengan strategi pelaksanaan ketiga bercakap-cakap dengan orang lain. Kemudian strategi pelaksanaan keempat yaitu melakukan kegiatan terjadwal. 
Setelah pasien mampu melakukan SP dengan mandiri, kemudian dilanjutkan dengan strategi pelaksanaan pada harga diri rendah. Pada strategi pelaksanaan pertama, mengidentifikasi kemampuan dan aspek positif yang dimiliki klien. Strategi pelaksanaan kedua yaitu menilai kemampuan yang dapat digunakan, memilih/menetapkan kegiatan sesuai dengan kemampuan, melatih kegiatan sesuai dengan kemampuan yang dipilih 1. Strategi pelaksanaan ketiga yaitu melatih kegiatan sesuai dengan kemampuan yang dipilih 2. Kemudian strategi pelaksanaan keempat yaitu melatih kegiatan sesuai dengan kemampuan yang dipilih 3.

\subsection{Diagnosa Keperawatan}

Risiko perilaku kekerasan terhadap orang lain adalah rentan melakukan perilaku yang menunjukkan dapat membahayakan orang lain secara fisik dan emosional (Nanda, 2018). Menurut Keliat (2019) Diagnose keperawatan yang yang menjadi penyebab RPK adalah :

1. Waham

2. Halusinasi

3. Berencana bunuh diri

4. Gangguan Konsep diri (Harga diri rendah)

5. Isolasi social

Sedangkan pada Tn.B ditemukan 3 diagnosa keperawatan yang muncul yaitu Risiko perilaku kekerasan, halusinasi dan harga diri rendah. Dari hal tersebut dapat dilihat ada beberapa perbedaan antara teori dengan kasus, yaitu tidak semua diagnose pada teori dialami oleh Tn.B.

\subsection{Tahap perencanaan}

Perencanaan dalam proses keperawatan lebih dikenal dengan rencana asuhan keperawatan yang merupakan tahap selanjutnya setelah pangkajian dan penentuan diagnosa keperawatan. Pada tahap perencanaan penulis hanya menyusun rencana tindakan keperawatan sesuai dengan pohon masalah keperawatan yaitu :perilaku kekerasan. Pada tahap ini antara tinjauan teoritis 
dan tinjauan kasus tidak ada kesenjangan sehingga penulis dapat melaksanakan tindakan seoptimal mungkin dan didukung dengan seringnya bimbingan dengan pembimbing. Secara teoritis digunakan cara strategi pelaksanaan sesuai dengan diagnosa keperawatan yang muncul saat pengkajian. Adapun upaya yang dilakukan penulis yaitu :

1. Strategi Pelaksanaan pada Risiko Perilaku Kekerasan

> Melatih pasien mengontrol perilaku kekerasan dengan latihan fisik 1 :

Tarik napas dalam

$>$ Melatih klien mengontrol perilaku kekerasan dengan latihan fisik 2 :

Pukul Kasur bantal

> Menjelaskan cara mengontrol perilaku kekerasan dengan minum obat

> Melatih klien mengontrol Risiko Perilaku Kekerasan dengan berbicara baik-baik dengan orang lain

$>$ Mengevaluasi spritual klien

2. Strategi Pelaksanaan pada Halusinasi

> Mengidentifikasi isi, frekuensi, waktu terjadi, situasi pencetus perasaan dan respon halusinasi

> Melatih klien mengendalikan halusinasi dengan cara menghardik

$>$ Melatih klien mengendalikan halusinasi dengan minum obat teratur

$>$ Melatih klien bercakap-cakap dengan orang lain

$>$ Melatih klien melakukan kegiatan terjadwal

\section{Strategi Pelaksanaan pada Harga Diri Rendah}

mengidentifikasi kemampuan dan aspek positif yang dimiliki klien.

$>$ menilai kemampuan yang dapat digunakan,

> memilih/menetapkan kegiatan sesuai dengan kemampuan,

$>$ melatih kegiatan sesuai dengan kemampuan yang dipilih 1 .

$>$ melatih kegiatan sesuai dengan kemampuan yang dipilih 2 .

$>$ melatih kegiatan sesuai dengan kemampuan yang dipilih 3 .

\subsection{Tahap Implementasi}

Pada tahap implementasi, penulis mengatasi 3 masalah keperawatan yakni: diagnosa keperawatan Risiko Perilaku Kekerasan, Halusinasi dan Harga Diri 
Rendah. Pada diagnosa keperawatan Risiko Perilaku Kekerasan dilakukan strategi pertemuan yaitu mengidentifikasi Perilaku Kekerasan, mengontrol perilaku kekerasan dengan cara tarik napas dan pukul kasur bantal. Strategi pelaksanaan yang kedua yaitu anjurkan minum obar secara teratur, strategi pelaksanaan ketiga yaitu latihan dengan cara komunikasi secara verbal atau bicara baik-baik strategi pelaksanaan ke empat yaitu Spritual.

Setelah diterapkan keempat strategi pelaksanaan pada risiko perilaku kekerasan, kemudian dilanjutkan dengan strategi pelaksanaan pada halusinasi pendengaran. Strategi pertama meliputi mengidentifikasi isi, frekuensi, waktu terjadi, situasi pencetus, perasaan dan respon halusinasi serta cara mengontrol halusinasi dengan menghardik. Strategi pelaksanaan kedua yang dilakukan pada Tn.B adalah minum obat secara teratur. Setelah itu dilanjutkan dengan strategi pelaksanaan ketiga bercakap-cakap dengan orang lain. Kemudian strategi pelaksanaan keempat yaitu melakukan kegiatan terjadwal.

Setelah pasien mampu melakukan SP pada Halusinasi dengan mandiri, kemudian dilanjutkan dengan strategi pelaksanaan pada harga diri rendah. Pada strategi pelaksanaan pertama, mengidentifikasi kemampuan dan aspek positif yang dimiliki klien. Strategi pelaksanaan kedua yaitu menilai kemampuan yang dapat digunakan, memilih/menetapkan kegiatan sesuai dengan kemampuan, melatih kegiatan sesuai dengan kemampuan yang dipilih 1. Strategi pelaksanaan ketiga yaitu melatih kegiatan sesuai dengan kemampuan yang dipilih 2. Kemudian strategi pelaksanaan keempat yaitu melatih kegiatan sesuai dengan kemampuan yang dipilih 3 .

\subsection{Tahap evaluasi}

Pada tinjauan teoritis evaluasi yang diharapkan adalah:

1. Pada Risiko Perilaku Kekerasan

- Klien mempercayai perawat sebagai terapis

- Dapat mengidentifikasi dan mengontrol Risiko Perilaku Kekerasan 
- Mampu mengendalikan Risiko Perilaku Kekerasan melalui latihan fisik,

- Mampu mengendalikan Risiko Perilaku Kekerasan dengan cara minumobat secara teratur

- Mampu mengendalikan Risiko Perilaku Kekerasan dengan berbicara baik-baik

- Mampu mengendalikan Risiko Perilaku Kekerasan dengan spritual yang terjadwal.

5. Pada Halusinasi

- Mampu mengidentifikasi isi, frekuensi, waktu terjadi, situasi pencetus perasaan dan respon halusinasi

- Mampu mengendalikan halusinasi dengan cara menghardik

- Mampu mengendalikan halusinasi dengan minum obat teratur

- Mampu latihan bercakap-cakap dengan orang lain

- Mampu melakukan kegiatan terjadwal

6. Pada Harga Diri Rendah

- Mengetahui kemampuan dan aspek positif yang dimiliki.

- Mampu menilai kemampuan yang dapat digunakan,

- Mampu memilih/menetapkan kegiatan sesuai dengan kemampuan,

- Mampu melatih kegiatan sesuai dengan kemampuan yang dipilih 1.

- Mampu melatih kegiatan sesuai dengan kemampuan yang dipilih 2.

- Mampu melatih kegiatan sesuai dengan kemampuan yang dipilih 3.

Pada tinjauan kasus evaluasi yang dihasilkan adalah :

1. Pada Risiko Perilaku Kekerasan

- Klien mempercayai perawat sebagai terapis

- Dapat mengidentifikasi dan mengontrol Risiko Perilaku Kekerasan

- Mampu mengendalikan Risiko Perilaku Kekerasan melalui latihan fisik,

- Mampu mengendalikan Risiko Perilaku Kekerasan dengan cara minum obat secara teratur 
- Mampu mengendalikan Risiko Perilaku Kekerasan dengan berbicara baik-baik

- Mampu mengendalikan Risiko Perilaku Kekerasan dengan spritual yang terjadwal.

2. Pada Halusinasi

- Mampu mengidentifikasi isi, frekuensi, waktu terjadi, situasi pencetus perasaan dan respon halusinasi

- Mampu mengendalikan halusinasi dengan cara menghardik

- Mampu mengendalikan halusinasi dengan minum obat teratur

- Mampu latihan bercakap-cakap dengan orang lain

- Mampu melakukan kegiatan terjadwal

3. Pada Harga Diri Rendah

- Mengetahui kemampuan dan aspek positif yang dimiliki.

- Mampu menilai kemampuan yang dapat digunakan,

- Mampu memilih/menetapkan kegiatan sesuai dengan kemampuan,

- Mampu melatih kegiatan sesuai dengan kemampuan yang dipilih 1

- Mampu melatih kegiatan sesuai dengan kemampuan yang dipilih 2

- Mampu melatih kegiatan sesuai dengan kemampuan yang dipilih 3 


\section{BAB 5 \\ PENUTUP}

\subsection{Kesimpulan}

Setelah menguraikan tentang proses keperawatan pada Tn.B dan disimpulkan bahwa klien dapat mengontrol risiko perilaku kekerasan, mengendalikan halusinasi dan mengatasi harga diri rendah dengan terapi yang di ajarkan oleh mahasiwa. Dimana klien dapat melakukan terapi generalis yang telah diajarkan oleh mahasiswa. Maka dapat diambil keputusan sebagai berikut :

1. Pengkajian yang dilakukan tidak banyak berbeda dengan pengkajian teoritis dan penulis tidak mendapat kesulitan dalam pengkajian yang dilakukan

2. Dalam mengatasi masalah yang dihadapi klien, mahasiswa mapu Menyusun tindakan keperawatan sesuai dengan teoritis yang ada.

3. Dalam pelaksanaan tindakan keperawatan disesuaikan dengan perencanaan dan dapat dilaksanakan walaupun belum sepenuhnya dapat terlaksana.

4. Pada tahap evaluasi masalah yang dihadapi klien tidak teratasi semua sesuai dengan masalah klien.

\subsection{Saran}

- Bagi Mahasiswa

Mahasiswa/mahasiswa mampu menerapkan asuhan keperawatan sesuai dengan tahapan yang baik dan benar yang diperoleh selama Pendidikan baik secara akademik maupun di tempat praktek

- Bagi Pasien

Diharapkan pasien dapat menerapkan terapi SP yang telah diajarkan oleh mahasiswa pada klien sehingga mempercepat proses pemulihan pasien.

- Bagi Perawat

Diharapkan dapat menerapkan komunikasi terapeutik dalam pelaksanaan strategi pelaksanaan1-4 pada klien dengan risiko perilaku kekerasan sehingga dapat mempercepat proses pemulihan klien. 
- Bagi Institusi Pendidikan

Dapat meningkatkan bimbingan klinik kepada mahasiswa profesi ners sehingga mahasiswa semakin mampu dalam melakukan asuhan keperawatan pada klien -klien dengan risiko perilaku kekerasan

- Bagi Rumah Sakit

Laporan ini diharapkan dapat menjadai acuan dan referensi dalam memberikan asuhan keperawatan pada klien dengan risiko perilaku kekerasan 


\section{DAFTAR PUSTAKA}

1. Azis, N. R., Sukamto, E., \& Hidayat, A. (2018). Pengerun Terapi DeEkslasi Terhadap Perubahan Perilaku Pasien dengan Resiko Perilaku Kekerasan di Rumah Sakit Jiwa Daerah Atma Husada MahakamSamarinda. http://repository.poltekkes-kaltim.ac.id/id/eprint/797

2. Depkes, R.I., (2015) Hasil Riskesdas 2015 Departemen KesehatanRepublik Indonesia http://www.depkes .go.id/resource/download/general.

3. Dwi Prastya, F., \& Arum Pratiwi, S. K. (2017). Mekanisme Koping Pada Pasien Perilaku Kekerasan Dengan Risiko Menciderai Orang Lain Dan Lingkungan (Doctoral dissertation, Universitas Muhammadiyah Surakarta). http://eprints.ums.ac.id/id/eprint/52420

4. Hastuti, R. Y., \& Setianingsih, S. (2016). Pengaruh Cognitive Behaviour Therapy Pada Klien Dengan Masalah Keperawatan Perilaku Kekerasan Dan Halusinasi Di Rsjd. https://doi.org/10.26714/jkj.4.1.2016.7-12

5. Jaya, K. (2018). Buku Keperawatan Jiwa. Tangerang Selatan:Binarupa Aksara

6. Keliat, B.A \& Akemat (2016). Keperawatan jiwa : terapi Aktivitas kelompok. Ed.2. EGC

7. Keliat, B.A (2019). Asuhan Keperawatan Jiwa. Jakarta:EGC

8. Kemenkes RI. (2019).Riset Kesehatan Dasar, RISKESDAS.Jakarta: Kemenkes RI.

9. Nurhalimah. (2016). Keperawatan Jiwa. Jakarta Selatan : Pusdik SDM Kesehatan

10. Pardede, J. A., Keliat, B. A., \& Wardani, I. Y. (2013). Pengaruh Acceptance And Commitment Therapy Dan Pendidikan Kesehatan Kepatuhan Minum Obat Terhadap Gejala, Kemampuan Berkomitmen Pada Pengobatan Dan Kepatuhan Pasien Skizofrenia. FIK UI, Depok.

11. Pardede, J. A, sirait, D. Riandi, R, Emanuel, P \& Laia R. (2016). Ekspresi emosi keluarga dengan frekuensi kekambuhan pasien skizofrenia. Idea Nursing Journal, 7(3), 53-61. https://doi.org/10.52199/inj.v7i3.6446

12. Pardede, J. A. (2020). Standar Asuhan Keperawatan Jiwa Dengan Masalah Risiko Perilaku Kekerasan.Jurnal Keperawatan Jiwa

13. Pardede, J. A., \& Laia, B. (2020). Decreasing Symptoms of Risk of Violent Behavior in Schizophrenia Patients Through Group Activity Therapy. 
Jurnal Ilmu Keperawatan Jiwa,

291-300. http://dx.doi.org/10.32584/jikj.v3i3.621

14. Pardede, J. A., Keliat, B.A., \& Yulia, I. (2015). Kebutuhan Dan Komitmen Klien Skizofrenia Meningkat Setelah Diberkan Acceptance And Commitment Therapy Dan Pendidikan Kesehatan Kepatuhan Minum Obat. Jurnal Keperawatan Indonesia, 3(18), 157-166. $\underline{\text { http://dx.doi.org/10.7454/jki.v18i3.419 }}$

15. Pardede, J. A., Simanjuntak, G. V., \& Laia, R. (2020). The Symptoms of Risk of Violence Behavior Decline after Given Prgressive Muscle Relaxation Therapy on Schizophrenia Patients. Jurnal Ilmu Keperawatan Jiwa, 3(2), 91-100. http://dx.doi.org/10.32584/jikj.v3i2.534

16. Pardede, J. A. (2020). Decreasing Hallucination Response Through Perception Stimulation Group Activity Therapy In Schizophrenia Patients. Iar Journal of Medical Sciences, 1(6), 304-309.

17. Pardede, J. A., Siregar, L. M., \& Halawa, M. (2020). Beban dengan Koping Keluarga Saat Merawat Pasien Skizofrenia yang Mengalami Perilaku Kekerasan. Jurnal Kesehatan, 11(2), 189-196. http://dx.doi.org/10.26630/jk.v11i2.1980

18. Pardede, J. A., Siregar, L. M., \& Hulu, E. P. (2020). Efektivitas Behaviour Therapy Terhadap Risiko Perilaku Kekerasan Pada Pasien Skizofrenia Di Rumah Sakit Jiwa Prof. Dr. Muhammad Ildrem Provsu Medan. Jurnal Mutiara Ners, 3(1), 8-14. http://114.7.97.221/index.php/NERS/article/ view/1005

19. Parwati, I. G., Dewi, P. D., \& Saputra, I. M. (2018). Asuhan Keperawatan Perilaku Kesehatan.

20. Pitayanti, A., \& Hartono, A. (2020). Sosialisasi Penyakit Skizofrenia Dalam Rangka Mengurangi Stigma Negatif Warga di Desa Tambakmas Kebonsari-Madiun. Journal of Community Engagement in Health, 3(2), 300-303. https://jceh.org/index.php/JCEH/article/view/83/78

21. Riskesdas (2018) Hasil Utama riskesdas 2018 Kementrian Kesehatan Badan Penelitian dan Pengembangan Kesehatan.

22. Pardede, J. A., Siringo-ringo, L. M., Hulu, T. J., \& Miranda, A. (2021). Edukasi Kepatuhan Minum Obat Untuk Mencegah Kekambuhan Orang Dengan Skizofrenia. Jurnal Abdimas Mutiara, 2(2), 1-5.

23. Sulistiowati, N. M. D., Keliat, B. A., \& Wardani, I. Y. (2014). Pengaruh acceptance and commitment therapy terhadap gejala dan kemampuan klien dengan resiko perilaku kekerasan. Jurnal Keperawatan Jiwa, 2(1), 51-57. https://doi.org/10.26714/jkj.2.1.2014.51-57 
24. Suryanti., Cannity, K., McIndoo, C. C., File, A. A., Ryba, M. M., Clark, C. G., \& Bell, J. L. (2018). Behavior Therapy for depressed breast cancer patients: Predictors of treatment outcome. Journal of Consulting and Clinical Psychology

25. Sujarwo, S., \& Livana, P. H. (2019). Studi Fenomenologi: Strategi Pelaksanaan yang Efektif untuk Mengontrol Perilaku Kekerasan menurut Pasien di Ruang Rawat Inap Laki-laki. Jurnal Keperawatan Jiwa, 6(1), 29-35

26. Suryenti, V. (2017). Dukungan Dan Beban Keluarga Dengan Kemampuan Keluarga Merawat Pasien Resiko Perilaku Kekerasan Di Klinik Jiwa Rumah Sakit Jiwa Provinsi Jambi Tahun 2017. Jurnal Psikologi Jambi, 2(2), 39-46. https://www.online-journal.unja.ac.id/jpj/article/view/4795

27. WHO (2019). Schizophrenia. Retrieved from. https://www.who.int/newsroom/factsheets/\%20detail/schizophrenia

28. Widyastini, B.I. (2014). Pengaruh Terapi Aktivitas Kelompok : Stimulasi Persepsi Sesi I - V Terhadap Kemampuan Mengontrol dan Mengekspresikan Marah Pada Pasien Risiko Perilaku Kekerasan di RSJD Dr. Amino Gondohutomo Semarang. Jurnal mahasiswa bidang ilmu $\begin{array}{llll}\text { keperawatan. } & 1 & \text { (1) } 2014 .\end{array}$

29. Yusuf, AH. (2015) Buku Ajar Keperawatan Kesehatan Jiwa. Jakarta Selatan : Salemba Medik. 
Keperawatan Jiwa

Febri Warni Hulu 